\title{
CONCEIVING CORPORATE GOVERNANCE FOR AN ASIAN ENVIRONMENT
}

\author{
David C. Donald*
}

Nearly all Chinese corporations are vehicles used by a separate system or social network-such as a family, a state, or a political party. Available data show a similar pattern in other Asian countries. The challenges presented by the corporation operating as a system within a system are in most instances ignored by the modern business corporation structure and related doctrine. This is just as true under Chinese and Hong Kong law as under that of the United States or the United Kingdom. The dominant model of corporate governance understands the company as a vehicle in which financial investors and operational management coexist for the sole purpose of profit. Other systematic relationships among persons operating the corporation are recognized only as potential sources of power and information asymmetries that exploit financial investor constituencies. This ignores both data on who owns most companies and a deep body of empirical scholarship demonstrating the advantages enjoyed by family enterprises-from profitability and longevity to lower executive compensation and transaction costs.

This Article uses institutional and systems theory tools to begin development of a model of corporate governance dynamics that takes real account of the systems that coexist with the corporate vehicle. It uses the initial examples of the family and the political party to propose a corporate structure in which social networks and value systems can meaningfully communicate with the governance rules of the corporation.

\footnotetext{
* Professor, Faculty of Law, Chinese University of Hong Kong. The author would like to thank the Hong Kong Research Grants Council for the generous funding of this work under the Theme Based Research Project, "Enhancing Hong Kong's Future as a Leading International Financial Centre" (T31-717/12-R) and Peter Alphart and Paul Cheuk for providing valuable research support. Thanks also go to Bruce Aronson, Andreas Cahn, Simon Deakin, Bryan Druzin, Jyh-An Lee, Ugo Pagano, Samuli Sappänen, and Wang Jiangyu for their insightful comments in conversation and on an earlier draft of this paper. All mistakes remain my own.
} 
I. INTRODUCTION: CORPORATE LAW AND THE SOCIAL

ENVIRONMENT. .90

A. Governance Rules Focus on Individuals and Their Interests. .90

B. Coupling Companies and Other Systematic Networks.......95

C. Adjusting Corporate Governance to the Asian Social Environment.

II. COUPLING SOCIAL SYSTEMS AND CORPORATE LAW 100

A. From Individual to Network: Rendering Corporate Law User-Friendly. 100

B. Systems Theory Provides the Necessary Coupling Concepts.

III. Two Common Value Networks That Use the CORPORATION: FAMILY AND THE STATE

A. Family Firms: Loyalty Transcending Contract

B. The Family Firm in Asia....

C. Party Firms: Ideology and Ambition Transcending the Immediate Profit Motive

IV. AdJusting Corporate LAW WITH StRUCTURAL

COUPLINGS

A. How Current Corporate Law Flexibly Accounts for Its Environment.

1. Individuals Adhering to Rules Constituting a Single System 122

2. The Exceptional Role of the Financial System ..........124

3. Equitable Duties are Doors to Alternative Value Systems....

4. "Equitable Considerations" Are a First Step in Systemic Accommodation.

$B$. Coupling the Users of Corporations into Corporate Law.....

1. Legitimizing Family Use of the Corporate Form .......131

2. Legitimizing the CCP in Chinese SOEs .....................134

V. CONCLUSIONS 136 


\section{INTRODUCTION: CORPORATE LAW AND THE SOCIAL ENVIRONMENT}

\section{A. Governance Rules Focus on Individuals and Their Interests}

The governance rules of corporate law seek to align the interests and behavior of individual corporate actors in a way that best serves a company's economic performance. ${ }^{1}$ This is achieved by using duties to frame decision-making, specifying permitted and prohibited acts, requiring disclosure, and creating a series of incentives and disincentives for corporate actors. ${ }^{2}$ Governance rules use increasingly sophisticated techniques to channel the interests of individual players, but they are not designed to interact with entire networks of institutionally channeled interaction that are present in a

1 While arguments about the exact definition of corporate governance abound, the general goal expressed above corresponds to what is found both in codes formulated by public bodies and in scholarly analysis. See, e.g., OECD Principles OF CORPORATE GOVERNANCE Preamble 11 (2004) (stating that "[c]orporate governance involves a set of relationships between a company's management, its board, its shareholders and other stakeholders. Corporate governance also provides the structure through which the objectives of the company are set, and the means of attaining those objectives and monitoring performance are determined. Good corporate governance should provide proper incentives for the board and management to pursue objectives that are in the interests of the company and its shareholders and should facilitate effective monitoring."); JONATHAN R. MACEY, Corporate Governance: Promises Kept, Promises Broken 1 (2008) (stating that "corporate governance is about reducing deviance by corporations where deviance is defined as any actions by management or directors that are at odds with the legitimate, investmenthacked expectations of investors. Good corporate governance, then, is simply about keeping promises. Bad governance (corporate deviance) is defined as promise-breaking behavior."); Mark J. Roe, Political Determinants of Corporate Governance 203-204 (2003) (stating that "[c]orporate governance can be analyzed solely in terms of the inner workings of the corporation: the mechanical requirements for the board of directors, the degree to which minority stockholders are protected from insider machinations... [But] [f]or corporate governance, the [major sources of influence] are labor markets, politics, and capital and product markets."); MELvin ARON EISENBERG, THE Structure OF THE CORPORATION: A LEgAL ANALYSIS 1 (1976) (stating that "[c]orporate law is constitutional law; that is, its dominant function is to regulate the manner in which the corporate institution is constituted, to define the relative rights and duties of those participating in the institution, and to delimit the powers of the institution vis-à-vis the external world.").

2 Reinier Kraakman et al., The Anatomy of Corporate Law: A Comparative AND Functional APPROACH 37-39 (2d ed. 2009) (stating that these strategies can be organized into a schema as appointment rights, decision rights, agent incentives, agent constraints and affiliation terms). 
corporation's environment. $^{3}$ The only exception to this characteristic of corporate law design is the network of the financial system, the needs of which are deeply imbedded not only in the design of the corporate shares' transferability, ${ }^{4}$ but also in rules on management and shareholder behavior when operating, and particularly when financing, the company. ${ }^{5}$ Other systematic networks of values, such as the family or the state, actively define relationships among the owners of most corporations, ${ }^{6}$ but corporate law does not adjust specifically to take them into account as useful systems. Ethical frameworks like those found in "corporate social responsibility" (CSR) or "corporate sustainability" also present value systems that could define relationships among corporate actors, but these positions are recognized at most through disclosure requirements, with no integration into company operation other than by appeals to investor preference and an ethical belief that one can "do well" financially by "doing good."

3 The environmental factors on which this paper focuses can be thought of as a system of values or 'motivation matrix' that assigns incentives and its own unique functional values to objects or actions. It can be understood either objectively (a matrix of values established systemically) or subjectively (a matrix of value choices made by a member of the system, qua member). The values determined in one system may overlap with those fixed in other value systems or may differ therefrom. For example, the profit motive enshrined in the system of company law will correspond to a key drive of either the family or the state when using the corporate form.

${ }^{4}$ See Frank H. Easterbrook \& Daniel R. Fischel, Limited Liability and the Corporation 52 U. CHI. L. REV. 89 (1985) (explaining that a primary function of limited liability, the most unique characteristic of the stock corporation, is to allow free transferability of shares).

${ }^{5}$ As a company moves closer to the capital market (from private to public or closely held to widely held) and is eventually listed, corporate law allows major changes to take place to the company's board structure, the decision-making prerogative of shareholders, and the structure of its share capital. These changes are seen as not only acceptable, but also necessary because linking into the financial system is understood to be a completely natural and desirable aspect of the company's existence.

${ }^{6}$ Figures on family firms and state owned corporations are discussed in detail in Part III, Section A. The special problems of corporate groups could also benefit from the systematic analysis offered here. The major tension of a group is that the systematic drive of the group's aims straddles individual companies and can come into conflict with corporate law as it applies to such companies.

7 Empirical studies have indeed shown that socially directed investment can be profitable. See, e.g., Jacob Gray et. al, Wharton Social Impact Initiative of the University of Pennsylvania (WSiI), Great Expectations: Mission Preservation AND FinANCIAL PERFORMANCE IN IMPACT INVEsting (2015), https://socialimpact.wharton. upenn.edu/wp-content/uploads/2016/09/Great-Expectations-Mission-Preservation-andFinancial-Performance-in-Impact-Investing.pdf [https://perma.cc/7DYJ-BHEF] (explaining that socially directed investment can be profitable). However, this does not in any way affect 
Not only do networks of value like the family greatly determine interpersonal relationships in most companies, but it has been shown repeatedly that they make tangible contributions to corporate operations. ${ }^{8}$ The presence of such systems is, however, at best taken into account in a cosmetic way (disclosure on CSR) and at worst condemned in advance as dangerous (family ownership equals crony governance). The family is understood primarily as an impediment to the corporation's fair and efficient operation. State ownership is seen as an impediment to a corporation's profitability, and ethical or social goals are generally tolerated to the extent that they do not disrupt the drive to profit. This exclusion can occur without notice because very little effort is made to grasp how the corporation interacts systematically with its real environment. For example, if a corporation were used as a vehicle for a family business, the matrix of family values might well attribute importance to an end like "promotion of autonomous family control," but corporate law could alternatively categorize the actions serving this end as abusive entrenchment, so that a key aim of the family-held corporation would be condemned a priori as illegitimate.

The regulatory thrust of corporate law is to bring individual interests of corporate actors into sync with the network of assigned corporate roles and tasks. ${ }^{9}$ Regardless of whether a given interest derives from a network of values having great social importance, if the interest has not yet been brought within the set of individual interests made legitimate through corporate law, it will come under consideration for sanction. The main stated aim of penalizing such action is to protect shareholders or minority shareholders from abuse, but there is no reason to doubt that this aim could be achieved even when corporate law takes into account the complexity of its real environment. Currently, most corporate governance rules are designed to single out and exorcise individual actions of corporate

the design of corporate law to offer a vehicle in which individuals may pursue profit by collective action through the proxy of the corporate vehicle.

${ }^{8}$ Part III, Section A of this Article contains a discussion of such factors.

9 Affirmative powers, such as the right to call or vote at a meeting, or to allot shares or enter into a business combination, are assigned in ways to allow efficient operation of the company while respecting a balance of power within the company; whereas, duties of care and of loyalty (in the United Kingdom, the fiduciary duty) direct behavior to the good of the company and its members. See, e.g., the discussion of agency problems and legal strategies in KRAAKMAN ET AL., supra note 2, at 39-49. 
players if they are seen as in conflict with the company's (or shareholders') good. ${ }^{10}$ This occurs regardless of whether such actions derive from competing networks of significant importance for society, or even for the long-term existence of the company- such as the family, a political party, a religion, a philosophy of CSR, ethical investing, or some other grid of norms. These alternative networks taken as a whole remain alien to the fabric of corporate law, and they are informally assigned values ranging from cosmetic to disruptive and even to sinister. ${ }^{11}$

Only specialized studies, such as those on the "family firm,"12 make any attempt to incorporate the interests that arise from competing value systems within the defined dynamics of corporate law. Otherwise, the motivations generated by such value networks are simply excluded or subjected to disclosure, and perhaps sanitation,

${ }^{10}$ Conflicts of interest and potential conflicts of interest (related-party transactions) are the target of the fiduciary duty (in the U.K. tradition) and the duty of loyalty (in the U.S. tradition). The conflict arises between a duty to the company (or its shareholders) and a personal interest of the corporate actor (director or controlling shareholder in the United States), and such personal interests will include the interests of related parties, such as family members of the corporate actor. See, e.g., ANDrEas CAHN \& DAVID C. Donald, Comparative Company LaW: Text and Cases on the Corporate LaWs of Germany, THE UK AND THE USA 332-368 (1st ed. 2010) (containing a discussion of the duties and related cases).

11 Rafael La Porta et al., Corporate Ownership Around the World, 54 J. Fin. 471, 510 (1999) (stating that "[f]amily control may facilitate corruption because it gives the controlling shareholders enormous autonomy in decision making, keeps the potential whistle-blowers out of major corporate decisions, and thus reduces the risk of getting caught. According to this theory, family control is especially important in the most corrupt countries."). On state control, see Richard MCGREgOR, THE PARTY: THE SECRET WORLD OF CHINA's COMMUNIST RULERs 9-10 (2010) ("The modern world is replete with examples of elite networks that wield behind-the-scenes power . . . The United Kingdom had the 'old boy network' ... . France has 'les énarques' ... Japan has the Todai elite . . . None can hold a candle to the Chinese Communist Party, which takes ruling-class networking to an entirely new level. The 'red machine' [internal telephone] gives the party apparatus a hotline into ... the government-owned companies that China promotes around the world these days as independent commercial entities.").

12 For example, articles published in the Family Business Review or texts such as Morten Bennedsen \& Joseph P.H. Fan, The Family Business Map (2014) and SABine B. KLEIN, FAMILIENUNTERNEHMEN: THEORETISCHE UND EMPIRISCHE GRUNDLAGEN (2d ed. 2004) incorporate in very different ways particular aspects of family relationships into the operation of stock corporations, but in doing so clearly see family firms as a particular subset of corporations. Similar treatment for firms owned by a parent in a related industry and tied by supply contracts or firms owned by a parent in an unrelated industry as part of a diversified group are not viewed with a like level of cottage peculiarity. 
in their individual appearances. ${ }^{13}$ Given the obvious presence (if not dominance) of such value systems within corporations and their potential contribution to corporate operations, ${ }^{14}$ they should be brought expressly within corporate governance theory. This paper outlines one avenue to that end by using a systems theory analysis to frame a common ground on which to conceive, as "systems," both the company as a product of corporate law and the value networks that may strongly influence the relationships among company actors. The example this Article has chosen for beginning this undertaking is the Asian company, given the historical, cultural and economic circumstances that have led to a prominent position for either the family or the state in many Asian corporations, large and small.

There is good reason for using both the family and the state (or political party) as two main examples of value networks to be integrated into corporate governance, and limiting analysis to those two systems. In their histories, these two value systems have often been diametrically opposed politically after the fall of dynastic royalty - the powerful families were no friends of state power, and communist governments in particular made great efforts to purge the royal and bourgeoisie families from a prominent role in the economy. ${ }^{15}$ By examining them both, this paper abstracts away from a single social phenomenon or political stance and formulates a scheme of corporate governance that allows an entire system of values to be integrated into that system we call corporate governance. Once this framework has been set out, it will facilitate a next step into less traditional value systems, such as philosophies of CSR or corporate sustainability. The aim of this analysis is to provide a systemic view of company law that allows it to interlock with its environment. This is undertaken in an apolitical way, completely agnostic as to whether wealthy families, a socially engaged state, or profit-seeking investors should take stewardship of an economy.

13 Criteria for independence applied to directors filter out those with family ties to an interest to be avoided, and disclosure of related-party transactions ensure that intersections with an alternative value network like a family are made known. Both are discussed in Part IV.

14 See infra the discussion in Part III.

15 Sheila Fitzpatrick, Everyday Stalinism 142 (1999) (quoting, "In the 1920s, Communist attitudes toward the family were often hostile. 'Bourgeois' and 'patriarchal' were two words often coupled with 'family.' The conventions observed by respectable society before the revolution were dismissed as 'petty-bourgeois philistinism."”). 
This would allow an opening of corporate law to various environments, well beyond the financial system, which currently presents the company's most legally acceptable matrix of use, purpose and design. ${ }^{16}$

\section{B. Coupling Companies and Other Systematic Networks}

In developing a resourced-based analytical model to isolate and evaluate the effect on corporate performance of control by a family, Habbershon and Williams summarize the need to understand how the two systems of "family" and "firm" interact and also note the incentives pushing corporate law to simply exclude the exogenous network from the inner workings of the firm:

There is also the broader problem of connecting complex behavioral and social phenomena within family businesses to traditional performance criteria. The systemic relationship between the family and the business creates categories of organizational behavior that are not easily identified as components of value creating strategies. It appears easier to ignore or rid the firm of the complexity, rather than address the sources of complexity as a potential for advantage. ${ }^{17}$

When corporate law ignores or flatly prohibits influence from the complex networks of motivations found in groups operating a firm, it takes the simpler route; however, this strategy merely turns a blind eye to motivations that are not only present in most companies, but can also lower transaction and agency costs within the firm. ${ }^{18}$

16 As will be discussed in Part IV, Section A.2, the corporate form and rules of corporate law have been generously adjusted over the last century to facilitate the connection between the company and the financial system. Connection to and influence by the financial system is not seen as external to the company and in any way dangerous - as would be ownership by a family or the state - but rather a feature that enlivens the company and brings it to itself.

17 Timothy G. Habbershon \& Mary L. Williams, A Resource-Based Framework for Assessing the Strategic Advantages of Family Firms, 12 FAM. Bus. Rev. 1, 6 (1999).

18 This paper focuses primarily on the rules of corporate governance found in U.S. and U.K. law, with additional specific reference to Hong Kong (which greatly resembles the United Kingdom). It could be argued that German law does a better job of allowing alternative networks to coexist within the firm, and codetermination is just one example of 
Leading jurisdictions have been prepared to alter the form of the business corporation in many ways, such as to optimize tax treatment with limited liability companies or allow sole proprietors to incorporate alone. ${ }^{19}$ Thus, it is more than just a little unusual that through roughly 200 years of modern corporate history, ${ }^{20}$ no concrete steps have been taken toward creating a system of company relationships that seriously engages the operative environment of business corporations.

When the management of a corporation is understood as a collection of individuals whose interests must be aligned to that of the company (or its shareholders, qua investor) or be excluded, factoring in networking systems from the environment is difficult, even if such systems are employing the company as a vehicle for their business. An individual is not a network of values but can interact with other actors within one. The lack of a systematic approach linking the company and the systems that affect relationships among its members abstracts away from real actors and posits hypothetical individual corporate actors with a pure profit drive. The real actors as found in the environment from which they originate are then supposed to have tendencies to engage in self-interested transactions $^{21}$ or make unwise decisions diverging from the profit incentive. $^{22}$ If, as estimates show, most companies are incorporated for use by a family or the state, it is inappropriate that such use of the

such systematic inclusion. The proposals offered in this paper remain within the framework of U.S., U.K., and Hong Kong law and do not tack onto the many attempts to bring German principles or constructs into the "Anglo-American" corporate law model.

19 See, e.g., Larry E. Ribstein, Making Sense of Entity Rationalization, 58 Bus. Law. 1023 (2003) (explaining rationalizations behind the emergence of limited liability companies).

20 See, e.g., Henry Hansmann et al., Law and the Rise of the Firm, 119 HARV. L. Rev. 1335, 1393-95 (2006) (stating that the New York General Incorporation Act of 1811 can be seen as the first modern corporate law).

${ }^{21}$ Randall Morck \& Bernard Yeung, Family Control and the Rent-Seeking Society, ENTREPRENEURSHIP, THEORY AND PRACTICE 391, 405 (2004) (arguing that trust among the family members, which is essentially a network effect of the family, leads to rent-seeking and corruption in a family firm, so that "[p]rofessional managers with brief careers might be socially preferable to enduring family control over large corporations.").

22 McGregor, supra note 11, at 101. McGregor discusses with disparaging amusement how executives of China's state owned enterprises were not permitted to cash in the "windfalls of millions of dollars through options granted to them after offshore listings," as they were rather forced to pledge such profits to the state if they wanted to move up in the communist party hierarchy. 
corporate form should trigger suspicion of abuse. Moreover, at least with regard to family firms, numerous studies have shown that the family network influences company operations in beneficial ways, ${ }^{23}$ so ignoring such networks or excluding them from corporate law probably damages the enterprise. Corporate law should provide a coupling that preserves the operational nature of both the environmental network of values (such as a family) and, in particular, those corporate governance rules designed to stop the corporate form from becoming an arena for extracting rents and abusing outside investors.

Systems theory is the natural tool to bring the systems of corporate law on the one hand, and intersecting networks of values and motivations (like the family or the state) on the other hand, into interoperable coordination. ${ }^{24}$ Luhmann, in particular, has offered valuable theoretical insights on how both law and society function as separate and self-generating systems that are linked dynamically. ${ }^{25}$ Luhmann isolates certain legal concepts and examines their function using the term "structural couplings," as they link law to its larger social environment. ${ }^{26}$ For example, items important in society, such as land, money, and technology, are linked to legal systems through the concept of property in the form of leases, negotiable instruments, and patents. The legal concepts take their shape from the needs of the real, social phenomena, and the social forms of possession and transfer of these phenomena take shape according to the conceptual structure of the legal system. Luhmann's configuration of the

${ }^{23}$ Primarily because family control tends to mean a long-term business outlook, reduced transaction costs in the company among members of the family network, and reduced agency costs due to informal bonding arising from family relationships. For a discussion of the effects of families on firms, see Part III, Section A.

24 Timothy G. Habbershon, Mary Williams \& Ian C. MacMillan, A Unified Systems Perspective of Family Firm Performance, 18 J. Bus. Venturing 451, 453 (2003) ("For nearly 2 decades, the two or three overlapping circles models ... have been the standard theoretical models for picturing family and business as interlinking systems that explain the competitive tensions in strategy making.”). See also James J. Chrisman et al., A Unified Systems Perspective of Family Firm Performance: An Extension and Integration, 18 J. Bus. VENTURING 467 (2003) (extending and integrating the theoretical contributions of Habbershon et al. by substituting value creation for wealth creation as the defining function of family businesses).

25 See Niklas Luhmann, Das Recht der Gesellschaft [Law as a Social System] 550 (1993).

${ }^{26}$ Id. at $440-495$. 
"structural coupling" is a good framework for expressly recognizing systematic networks of social values intersecting with and inside of corporate law. Existing concepts in corporate governance can be adjusted and new concepts can be formulated to give legal substance to real systems of relationships defining interactions among corporate actors.

\section{Adjusting Corporate Governance to the Asian Social Environment}

While the available, largely estimated data shows family firms are dominant globally, with approximately half of U.S.-listed companies, and about $60 \%$ of all European businesses, controlled by families, ${ }^{27}$ there are good reasons why Asia is an appropriate starting point for a project opening corporate governance to environmentally prominent networks of values. First, family firms are statistically more prevalent in the Asian private sector than they are in the West. ${ }^{28}$ Second, and perhaps most importantly, the history of Asia diverges from that of the West in ways that have left the ancient importance of the extended family relatively intact. ${ }^{29}$ Third, Asian countries have without exception imported their corporate law. The models were originally developed in Western countries and transplanted voluntarily, through colonization, or following military victory. ${ }^{30}$ As

27 Global Data Points, FAM. FIRM Inst., http://www.ffi.org/?page=globaldatapoints [https://perma.cc/GS9C-5HUS] (last visited Feb. 17, 2017).

${ }^{28}$ Family firms constitute an estimated $85 \%$ of China's private enterprises and about $79 \%$ of "organized private sector employment" in India. Id.

29 As will be discussed in Part III, Section B, history shows that Christianity in Europe did much to dissolve the power of ancient clans over the individual as a holder of rights, which freed the individual for primary membership in other organizations, such as the early corporations operating municipalities and guilds.

${ }^{30}$ On the transplantation of corporate law into mainland China, see JiANGYU WANG, COMPANY LAW IN CHINA 3-7 (2014) (discussing a brief history of China's company law). On the transplantation into colonial Hong Kong, see David C. Donald, A Financial Centre for Two Empires: Hong Kong's Corporate, Securities and Tax Laws in its TRANSITION FROM BRITAIN TO CHINA 104-169 (2014) (discussing the development of Hong Kong's corporate and securities laws as a response to Hong Kong being China's international financial center). On the shaping of Japanese company law following World War II, see Bruce Aronson, Postwar Reform of Corporate Law and Corporate Governance: Democratization under the Occupation and the Japanese Reaction, in LAW AND PRACTICE IN Postwar Japan: The Postwar Legal Reform AND their Influence 59 (International House of Japan \& Blakemore Foundation eds. 2010) (discussing two opposing views on the necessity and success of reforming of Japanese corporate law in 1950); see also Hideki 
such, they have a law that did not grow out of their social institutions. Fourth, given the current point of China's economic development in its transition away from a fully planned economy, most of China's globally significant firms are state owned enterprises (SOEs). As will be discussed in Part III, Section C, the Central Personnel Committee of the Chinese Communist Party (CCP) controls executive appointments and career advancement in these SOEs. For these reasons, the project of integrating actual networks of values from the social and political environment into corporate governance can favorably begin with Asia.

A good specimen of corporate law on which to focus while attempting to link environmental systems to the system of corporate governance is that of Hong Kong. Hong Kong's company law originated in and remains very close to that of the United Kingdom, both in statutory and common law elements. ${ }^{31}$ U.K. law was passed to most of Britain's colonial network, has significant similarities to that of the United States, and has influenced E.U. company law. Hong Kong company law therefore presents a good example of the global standard for corporate law, making it one of the world's most important commercial laws. The economy of Hong Kong is dominated by companies controlled either by families or the People's Republic of China (PRC) ${ }^{32}$ so that abstract corporate doctrine of the detached individual engaging in the company to pursue personal profit is closely juxtaposed with the reality of value networks determining much of the behavior of corporate actors. Regulators and lawmakers are aware that the socioeconomic character of Hong Kong does not always match the governance model codified in corporate law and have made some small adjustments to the standard corporate law model. ${ }^{33}$ However, Hong Kong company law and

Kanda \& Curtis J. Milhaupt, Re-Examining Legal Transplants: The Director's Fiduciary Duty in Japanese Corporate Law, 51 AM. J. Comp. L. 887 (2003) (discussing the role of legal transplants in corporate law by examining Japan's transplantation of the director's duty of loyalty).

${ }^{31}$ For a history of the development of Hong Kong company law, see DonALD, supra note 30 , at 22-33 (discussing the foundations of Hong Kong's legal system), 111-22 (discussing law transplanted only as the need arose).

32 See Donald, supra note 30, at 62-101 (explaining the ownership of the largest companies in the major segments of Hong Kong's Hang Seng Index).

33 For example, the Model Articles for Public Companies provide for the possibility of a "managing director" who may be appointed without being subjected to future elections and may be given powers equal to those of the entire board, to the exclusion of the powers of the 
listing rules mirror international standards in large part by focusing on individuals and linking external value networks to conflicts of interest. Where this Article offers recommendations in the context of a specific body of corporate law, it will use Hong Kong law as a case study.

Following this introduction, Part II will present the tools used in this Article's system theoretic analysis. Part III examines the problem of companies operating at the intersection between corporate law and two major systems of roles and values, the family and the CCP. The first section of Part III will review existing scholarship on the family within the operation of corporations. The second section of Part III will discuss the way in which the roles and duties of the CCP enter into the operation of a corporation. Part IV will then examine the very limited way in which modern corporate governance theory interacts with major value systems operating in the environment, such as the financial system; systems of professional skills applied to assessment of the director's duty of skill, care, and diligence; and the equitable considerations that trigger a case of unfair prejudice. Part V will develop some workable structural couplings with which corporate governance can be fruitfully linked to networks of values that influence corporate actors within a firm. Part VI will offer conclusions.

\section{COUPLING SOCIAL SYSTEMS AND CORPORATE LAW}

\section{A. $\quad$ From Individual to Network: Rendering Corporate Law User-Friendly}

The company form is mostly used by families, the state, or political parties. The typical rules of corporate governance do not expressly prohibit company officers from bringing into the company interests they hold from membership in alternative environmental value systems. Motivations from such exterior sources are, however, essentially ignored unless they conflict with the perceived interest of the company or that of the shareholders qua investor (not as, say, a

other board members. Hong Kong Model Articles for Public Companies, arts. 33-34 (2013) http://www.gld.gov.hk/egazette/pdf/20131721/es22013172177.pdf [https://perma.cc/6DTL -2JL8]. 
family member or employee), in which case they are condemned. ${ }^{34}$ This is not surprising because law as a whole centers greatly on creating and enforcing rights and duties of individuals. ${ }^{35}$ However, the corporation always operates as a group, even if only a minimal group of one physical and one legal person; at the other end of the spectrum, the group can become very large. ${ }^{36}$

Moreover, corporations are vehicles through which to conduct business activity; they are not ends in themselves. The law enabled the creation of corporations to facilitate the activity of groups of people for their interaction with the world. ${ }^{37}$ As the aggregation

\footnotetext{
34 There is a significant difference between corporate law traditions in the United Kingdom and the United States on this point. Although the corporate law of the United States uniformly recognizes companies as separate entities, most states consider them to be somewhat porous when assigning duties, so that directors' duties flow through the company employing the director to the shareholders behind it. See, e.g., Revlon, Inc. v. MacAndrews \& Forbes Holdings, Inc., 506 A.2d 173, 182 (Del. 1986) (ruling that in the event of an inevitable takeover, the director has a duty to achieve the best price for the shareholders). In the U.K. tradition, the company's status as an entity is applied with more doctrinal coherence, so that a director's duties run to the company for which she serves as director and with which she has an employment contract. See Companies Act 2006, c. 46, § 172(1) (U.K.) [hereinafter Companies Act 2006] (adding a more porous element of "promote the success of the company for the benefit of its members as a whole" to the traditional formulation).

35 H. L. A. HART, The CONCEPT OF LAw 269 (Paul Craig ed. 3rd ed. 2012) (stating "legal rights and duties are the point at which the law with its coercive resources respectively protects individual freedom and restricts it or confers on individuals or denies to them the power to avail themselves of the law's coercive machinery.").

36 The very name “company” (Gesellschaft, societé, societá, 公司, 会社) indicates a social aspect, an association creating an enclosed society with its own set of rules. This aspect of companies is plainly visible from both historical and theoretical vantage points. The first companies chartered by the British crown operated as quasi-autonomous governments in colonies from North America to Asia. See, e.g., Janet McLean, The Transnational Corporation in History: Lessons for Today? 79 IND. L.J. 363, 367-75 (2004) (discussing the early successes of the English East India Company and other overseas trading corporations). From a conceptual perspective, German companies fall under the genus of club (Verein) or association. Recently, the U.S. Supreme Court has decided that corporations should enjoy a certain level of protection for their exercise of political and religious rights. Citizens United v. Fed. Election Comm'n, 558 U.S. 310 (2010); Burwell v. Hobby Lobby Stores, Inc., 134 S. Ct. 2751 (2014). However, neither decision delves into the nature of the company in a rigorous way.

37 See, e.g., Leo E. Strine, Jr. \& Nicholas Walter, Originalist or Original: The Difficulties of Reconciling Citizens United with Corporate Law History, 91 Notre Dame L. REV. 877, 891-99 (2016) (arguing that a corporation is a collection of many individuals, united into one body, with the capacity of acting particularly of taking and granting property, of contracting obligations, and of suing and being sued, of enjoying privileges and immunities in common, and of exercising a variety of political rights, according to the design of its institution, or the powers conferred upon it).
} 
of capital was a central function of the corporation, corporate law does recognize the authority of the financial system as a network of values beyond corporate law that may legitimately affect the company. ${ }^{38}$ The interest of an investor is only very rarely understood to be in conflict with the interest of the company. Exceptions are also made for networks of values created in professions related to the decision-making of corporate officers, such as accounting, risk management, or business planning. The values espoused in these professional cultures are both used by courts to flesh out the skill, care and diligence duty applied to company directors and can also define the interest of the company. ${ }^{39}$ Excluded value systems like the family are acknowledged primarily in the form of rules, checking motivations that might derive from them. This is accomplished by prohibiting or requiring disclosure and sanitation of individual decisions taken under the influence of such systems. The motivational assumption running in the background of modern corporate governance theory is that an individual profit motive aligned with that of the company should drive the interests of company participants. ${ }^{40}$

\footnotetext{
38 The key needs of the financial system are built into stock corporations: the transferability of shares makes a liquid investment possible, corporate personality with limited liability reduces the volatility of a company's value even when its ownership changes through the trading of its shares, and the rules of corporate governance are designed to make risk manageable, placing great stress on protecting minority shareholders (who are financial investors) and creditors. See infra Part IV, Section A.2.

39 The manner in which these exterior value systems are brought into corporate law is examined in Part IV, Section A.

40 This aspect of corporate law is so self-evident that it is rarely called out. However, an examination of law shows it is true of motivations whether they are viewed in a positive or a negative light by corporate law. In regulating conflicts of interest, Delaware General Corporation Law (DGCL) § 144 refers to a "director's or officer's [individual] relationship or interest," and when specifying standing to demand a fair price for shares in connection with a corporate combination this law refers to "any [individual] stockholder of a corporation.” Del. Code Ann. tit. 8, §§ 144, 262 (2013) [hereinafter DGCL]. Companies Act 2006 § 175(1) also refers to the individual director: "he has, or can have, a direct or indirect interest that conflicts" with that of the company. Companies Act 2006, supra note 34 , § 175(1). Although the right to petition for relief against unfairly prejudicial action refers to the members generally, it is the individual rights of each member that are indicated ("the company's affairs are being or have been conducted in a manner that is unfairly prejudicial to the interests of members generally or of some part of its members"). Companies Act 2006, supra note 34, § 994(1)(a). Although German law does refer to the management board (vorstand) as a collective (Aktiengesetz [Stock Corporation Act] § 76-77), it still deals with interests of individuals, such as in the noncompetition requirement expressed in $\S 88$, the duty of care expressed in $\S 91$, and the annual decision to approve behavior (entlasten)
} 
The result of this framework is that modern governance rules seek to hold the self-interests of corporate actors in check when they conflict with an operation of the company that is conceived to reap profit (whether immediately or through a visible causal chain). Through the work of Jensen and Meckling, efforts spent to control divergences between individual interest and the company's (or shareholders') interest are understood under the concept of "agency costs." 41 During most of the 20th century, the work of Berle and Means led scholars to focus on an agency problem between shareholders and the self-interested control of management. ${ }^{42}$ At least since the 1990s, it has been generally known that the "Berle \& Means corporation," defined by the characteristic of central management dominating dispersed shareholders, is not the global norm. ${ }^{43}$ During the 2000s, Kraakman et al. consolidated the theory of agency costs across the varying ownership structures found in major world economies, formulating a highly authoritative contemporary theory of comparative corporate law. ${ }^{44}$

expressed in $\S 120$. Aktiengesetz [Stock Corporation Act], Sept. 6, 1965, BGBl at 1089, as amended, § 76, § 77, § 88, § 91, § 120 (Ger.).

${ }^{41}$ Michael C. Jensen \& William H. Meckling, Theory of the Firm: Managerial Behavior, Agency Costs and Ownership Structure, 3 J. Fin. ECON. 305, 308-09 (1976).

42 Adolf A. Berle \& Gardiner C. Means, The Modern Corporation and Private Property 84 (1932). On the question of dispersed shareholding, see, e.g., Ronald J. Gilson \& Jeffrey N. Gordon, The Agency Costs of Agency Capitalism: Activist Investors and Revaluation of Governance Rights, 113 CoLuM. L. REV. 863 (2013) (arguing that equity ownership in the United States no longer reflects the dispersed share ownership of the canonical Berle-Means firm and explaining the reason of the reconcentration of ownership in the hands of institutional investment intermediaries, which gives rise to "the agency costs of agency capitalism."); Brian R. Cheffins and John Armour, The Past, Present, and Future of Shareholder Activism by Hedge Funds, 37 J. CoRP. L. 51 (2011) (explaining the rise of hedge funds as practitioners of offensive shareholder activism); John C. Coffee Jr., The Rise of Dispersed Ownership: The Roles of Law and the State in the Separation of Ownership and Control, 111 YALE L.J. 1, 37-39 (2001) (arguing NYSE's role of guardian of the public investor, and it imposed high listing standards for its own self-interested reasons and tracking how NYSE became identified with mandatory listing conditions that protected "shareholder democracy" and prevented the separation of cash flow rights from voting rights.).

43 As was noted in a well-known study published in 1999, "If we look at the largest firms in the world and use a very tough definition of control, dispersed ownership is about as common as family control. But if we move from there to medium-sized firms, to a more lenient definition of control, and to countries with poor investor protection, widely held firms become an exception. Berle and Means have created an accurate image of ownership of large American corporations, but it is far from a universal image." La Porta et al., supra note 11 , at 498.

${ }^{44}$ KRAAKMAN ET AL., supra note 2, at 35-37. 
This theory shows how the agency costs dynamic can be applied robustly to the relationship resulting from any kind of delegated authority, ${ }^{45}$ including that between directors and the company (or shareholders), between controlling and minority shareholders (power delegated by means of the majority control rule), or between shareholders and creditors (power delegated by the fact that creditors remain corporate outsiders despite providing the company with cash). ${ }^{46}$ In each case, governance rules are designed to mitigate the risks from a situation in which an agent constituent might try to serve his or her own self-interest to the detriment of the principal constituent, which may or may not be the company itself. Self-interest extends to interests of members within a value system, typically the family but also a related firm, to which the relevant corporate actor is also connected.

Differing political goals written into corporate law and differing socioeconomic circumstances can lead to different behavioral goals being ascribed to corporate actors. ${ }^{47}$ For example, if it is decided that the purpose of a company is to maximize profits for the benefit of shareholders, then power can be given to shareholders and competing interests are restricted. ${ }^{48}$ On the other

45 As Jensen and Meckling noted in 1976, “agency costs arise in any situation involving cooperative effort (such as the co-authoring of this paper) by two or more people even though there is no clear-cut principal-agent relationship." Jensen \& Meckling, supra note 41, at 309.

${ }^{46}$ KRAAKMAN ET AL., supra note 2, at 37-53.

47 Proving this point has been a central focus of the comparative corporate law work of Mark Roe. See RoE, supra note 1, at 3-5 (aiming to find a deep, important and missing political explanation for the rise of the large firm and the separation of ownership from control). Another important contribution on this topic is CuRTIS J. MilHaUPT \& KATHARINA Pistor, LAW \& CAPITALISM: What CoRPORATE CRISES REVEAL ABOUT LEGAL SySTEMS AND ECONOMIC DEVELOPMENT AROUND THE WORLD (2008) ("We . . . use corporate governance as a lens through which to view a much larger set of institutional phenomena in a given country and to analyze, as rigorously as possible, the relation between the legal system and the portion of the economic system that is directly related to firms' structures and governance.”).

48 Profit maximization for the benefit of shareholders is an object found strongly represented in the "nexus of contracts" theory of corporate law. See, e.g., FranK EASTERBROOK \& DANIEL FisChEL, THE ECONOMIC STRUCTURE OF CORPORATE LAW 91 (1991) ("[T]he corporate contract makes managers the agents of the equity investors but does not specify the agents' duties. To make such an arrangement palatable to investors, managers must pledge their careful and honest services."). The applicability of this understanding to Delaware law has recently been convincingly reaffirmed. See Leo E. Strine, Jr., The Dangers of Denial: The Need for a Clear-Eyed Understanding of the Power and Accountability Structure Established by the Delaware General Corporation Law, 50 WAKE FOREST L. REV. 
hand, if the object of a company is to thrive generally as an "undertaking," power can be distributed among key corporate constituencies and shareholder primacy restricted. ${ }^{49}$ If we eventually join the very peculiar view of the U.S. Supreme Court that conceives the corporation as a person enjoying the same protection as any other person-free of prejudice arising from the fact that it can be called artificial— civil and human rights can be attributed to the company. ${ }^{50}$ The only limits to this exercise are those provided by the political climate and respect for the internal coherence of legal doctrine. These allocations of rights to privileged constituencies will be created by assigning duties to other corporate actors to respect such rights. Thus, law ascribes duties to members of the board of directors and controlling shareholders in connection with the power they receive over the company from corporate law arrangements. ${ }^{51}$ Duties of care

761 (2015) (examining the argument that directors have no legal obligation to make the promotion of stockholder welfare their end under Delaware law).

49 Pursuant to $\S 76(1)$ of the German Stock Corporation Act, the managing directors have a duty to manage the company, "in the interest of the undertaking" (interesse des unternehmens or unternehmensinteresse), which is understood as constituted by a pool of interests from shareholders, employees, creditors and the community. HANS-JOACHIM MERTENS \& ANDREAs CAHn, KÖLNER Kommentar zUM AKTIENGESETZ, § 76, at 33-37 (3rd ed. 2010). This aggregated undertaking theory also underlines that the company 'in itself' is not seen as having an interest. FrIEDRICH KÜBLER \& HEINZ-DiETER AssmanN, GeSELlschaftSRECHT: DiE PRIVATRECHTLICHEN ORDNUNGSSTRUKTUREN UND REgELUngSPROBLEME VON VERBÄNDEN UND UnTERNEHMEN 178 (2006). The view of the company as an arrangement that serves and mediates the interests of a number of constituencies is also found in the United States, under the corporatism model promoted in the 1950s and in the "team production" model promoted in the late 1990s by Blair and Stout. Cheffins presents an excellent history of ideas analysis of the evolving views of the corporation in the United States. See Brian R. Cheffins, The Team Production Model as a Paradigm, 38 Seattle U. L. REV. 397 (2015) (drawing upon key corporate law theories and trends to offer insights concerning their model and showing team production theory is unlikely to achieve paradigmatic status within the realm of corporate law theory).

50 This is a potential direction the U.S. Supreme Court is moving when it declares that "the Government cannot restrict political speech based on the speaker's corporate identity." Citizens United v. Fed. Election Comm'n, 558 U.S. 310 (2010). The German constitution takes a similar view. Grundgesetz FÜr DIE BundesRepubliK Deutschland [GG] [Basic Law], May 23, 1949, BGBl. I, art. 19(3) [hereinafter GRUNDGESETZ].

51 Although not identical to the duties assigned to a trustee, the underlying structure is the same, and the duties reflect the legitimate claims of the persons who should benefit from the agent's action. See D. Gordon Smith, The Critical Resource Theory of Fiduciary Duty, 55 VAND. L. REV. 1399 (2002) (crafting a unified theory of fiduciary duty, in which fiduciary relationships form when one party (the fiduciary) acts on behalf of another party (the beneficiary), where the "on behalf of" requirement describes relationships in which one person acts primarily for the benefit of another). 
and loyalty serve to bend directors' potentially self-serving behavior toward the diligent and faithful management of the company for the benefit of the entity or its constituents.

In this way, comparative corporate scholarship has brought us to the point where governance mechanisms can be adjusted both to different manifestations of agency problems and to variations of corporate purposes, whether for profit maximization of shareholders or the benefit of a broader association of corporate constituencies. Despite this versatility, corporate governance generally presupposes that the moving force within a corporation is the individual profit incentive, whether in the form of executive compensation, capital gains and dividends, reliable payment of interest and principal, an enduring and fairly compensated employment relationship, or stable contracts of supply. Governance mechanisms are designed to allow profitable operation of the entity as a unit while safely channeling the individual actors' drives for self-gain, with each actor exercising delegated power on behalf of the entire company or another constituency. Declaring motivations other than profit is not entirely foreign to corporations, as the "mission statements" of many companies evince, ${ }^{52}$ but they are cosmetically added to the governance framework, not made integral to its operation. When the interaction of shareholders and executive managers is largely determined by values from an environmental system of values they share and they have taken recourse to the company form in order to

52 The year before Volkswagen AG was embroiled in what was perhaps history's most innovative premeditated fraud of environmental regulation, its Chairman proudly (or cryptically) announced in the company's annual report that, "[o]ur pursuit of innovation and perfection and our responsible approach will help to make us the world's leading automaker by 2018 - both economically and ecologically." VolKswagen AKTIEngesellschaft ANNUAL REPORT 4 (2014). At the height of a period - as it was later determined by courtsin which Volkswagen bribed its board labor representatives with extravagant parties and prostitutes to obtain their support for management initiatives, its Chairman wrote proudly (or cryptically) under the heading "Group Values," that "the art of good leadership is to give employees yardsticks by which they can measure the soundness of their own decisions, and to urge them to make use of that freedom." VolKswagen AKTIEngESELlschaft ANNUAL REPORT 14 (2003). The criminal proceedings on the first set of charges were concluded in January 25, 2007 with the decision of the District Court of Braunschweig, 6th Criminal Chamber (docket no. 48/06). For details on the scandal in English, see Dietmar Hawranek et al., Scandal at Volkswagen: With Prostitutes and Shady Executives, There's No Love Left in this Bug, Der SPIEgel OnLine (July 18, 2005), http://www.spiegel.de/international/ spiegel/scandal-at-volkswagen-with-prostitutes-and-shady-executives-there-s-no-love-leftin-this-bug-a-365752.html [https://perma.cc/JU3Y-YVJH]. 
carry out ends grounded in such system, ignoring this fact renders corporate law defective and ill-suited to its task.

\section{B. $\quad$ Systems Theory Provides the Necessary Coupling Concepts}

When the law governing the most important organizational form in business ignores the most prominent societal value systems that use such a form, there is a serious gap between law and reality. The abstraction presupposed in law pulls individuals out of their environment - a system of values that may have the shape of their activity later brought into the corporate form. Although this system of values may be the primary determinant of how corporate actors relate to each other, corporate law will either ignore the actor's relationship to this network or condemn it as a source of conflicted interest. To correct this situation, the process of abstraction must be reversed so that the individual corporate actor can be understood within both the corporation and the concrete matrix of motivations that place the actor in the corporation. This can be done by shifting from law's traditional focus on the individual to an analysis of systematic relationships. Concepts borrowed from systems theory as applied to law provide a workable bridge for this transition.

Systems theory has been used for decades to study the operation of family businesses. ${ }^{53}$ Deakin and Carvalho have also mapped out a system theoretic approach to company law that is wholly complementary to institutional studies, employing the theoretical framework developed by Niklas Luhmann. ${ }^{54}$ In an early work on systems theory, Luhmann explains why a successful governance analysis must look beyond individual conflicts of interest to the action of alternative motivational matrices:

Classical organization theory contains many problems and tends to attribute the fault for this to individuals, particularly members of organizations condemned of

53 See Trevor Hopper \& Andrew Powell, Making Sense of Research into the Organizational and Social Aspects of Management Accounting: A Review of Its Underlying Assumptions, 22 J. MgmT. STuD. 429 (1985) (providing an initial survey of the use of systems theory for the study of family firms in management studies).

54 Simon Deakin \& Fabio Carvalho, System and Evolution in Corporate Governance, at 7-8, (Eur. Corp. Governance Inst. Law, Working Paper No. 150/2010) http://ssrn.com/ abstract=1581746 [https://perma.cc/UZ9Q-V6T9]. 
not disclosing conflicts of role (duties). In this way, problems deriving from the relationship between the system and its environment are written off to weakness of character. ${ }^{55}$

While corporate law theory is built upon addressing conflicts of interest, it has never set out to confront entire systems of values and motivations arising from networks within society as they intersect with the corporation.

In his later work, Luhmann revisited this problem, and borrowed concepts from biology to conceive portals between the systems of law and society in the form of "structural couplings," which he distinguishes from "operative couplings," with the former being constant and the latter event-specific. ${ }^{56}$ In an operative coupling, a given event in one system impacts and takes on value in another system (e.g., a transfer of money extinguishes an obligation), while in a structural coupling, "a system continuously presupposes specific characteristics in its environment and structurally depends upon them" (e.g., using money to settle debts presupposes the legal nature of money). ${ }^{57}$ Structural couplings serve as enduring and selective portals between systems because they "limit and in this way facilitate environmental influences on the system," 58 like the membrane of a cell that absorbs only ions that are beneficial for the cell's development and rejects all others as unneeded or damaging.

Luhmann understands the legal concept of "property" as an essential coupling between the systems of "economy" and "law" because property "eliminates the need for consensus" in dealing with the social object, so "for the consequences of certain actions the owner's consent alone is sufficient." 59 In this way, Luhmann agrees with other prominent theorists in understanding the definition of property rights as a component of transaction costs, ${ }^{60}$ but his focus is

\footnotetext{
55 NikLAs LuHMANN, ZWECKBEGRIFF UND SystemRATIONALitäT 73-74 (Suhrkamp Verlag ed., 6th ed. 1999) (author's translation).

56 LUHMANN, supra note 25, at 441.

57 Id. (author's translation).

${ }^{58} I d$. (author's translation, emphasis added).

59 Id. (author's translation, italics omitted).

60 See, e.g., Douglass North, Institutional Change and Economic Performance 28 (1990) ("The total costs of production consist of the resource inputs of land, labor, and
} 
on the manner in which the link is channeled rather than its value to the economic system.

Luhmann explains the manner of communication between systems through analogy to the "irritations" and "surprises" an organism might experience in its environment. ${ }^{61}$ When the social system "irritates" the legal system through a "surprise" that the legal system is designed generally (though not specifically) to foresee, law will not respond automatically — transforming input to output-but instead process this irritation according to its own internal rules. ${ }^{62}$ Both the social system and the legal system will "simultaneously" register the irritation, but there will be a lag time in the law's reaction to the stimulus processing of the "surprise," so that the two systems are not "synchronized." 63 Whether the legal and social systems eventually line up with each other will determine the presence or absence of "corruption":

All conceivable pressures deform law, whether they ignore it and circumvent the applicable law or whether they cause the system case by case to call the legal illegal or the illegal legal. Without structural couplings in the relationship between subsystems of society, law remains corrupt, in the modern sense of the word .... The more fundamental question is, rather, which structural couplings in relation to other subsystems can make it possible for corruption to be displaced and simultaneously environmental influences to be reduced and-aided by the coupling -increased. ${ }^{64}$

capital ... and in transacting - defining, protecting, and enforcing the property rights to goods").

${ }^{61}$ LuHMANN, supra note 25, at 442.

$62 I d$. at 442, 453. The manner in which systems interact, but stabilize themselves internally is made evident in Luhmann's conceptual definition of rule of law. While the legal enforceability of a transfer of money has a real importance in the economy, it must be something "that cannot be paid for" (unbezahlbar), so that the two systems communicate but remain independent (author's translation, italics omitted).

${ }^{63}$ Id. at 442.

64 Id. at 445 . 
The corruption that occurs when law and society are out of sync is corrected by structural couplings that allow the two systems to communicate, so that the social activity creating the irritation can adjust law. Imagine an arrangement where A takes control of B's property with B's consent but without purchasing title to it, and behaves openly as the property's owner, transferring to B the fruits earned from the property. This apparent corruption of the ownership relationship can be repaired through either the property law concept of "trust" or the contract law concept of "agency," both of which would have specific constitutive elements that facilitate and limit their use.

As discussed in the previous section, no structural coupling has been designed to allow those major value networks (such as family or state) that use the corporate form to communicate effectively with corporate law and eliminate the corruption which occurs in both the social systems and corporate law when the two systems interact. On the contrary, corporate law has created rules on conflict of interest that are triggered if an individual corporate actor belongs to a family in which another member is dealing with the company through that actor. Neither the aim of the secondary system nor the corporate actor's duty to it are understood as relevant to the conflict of interest analysis. ${ }^{65}$ Preventing influence by such value systems is considered a best-practice stopgap against evasion, undertaken to protect the interests of outside investors so they can place funds into a company without fear of abuse by insiders. ${ }^{66}$ The absence of a workable coupling between the systems that control most companies and the law according to which these companies operate appears to be a choice that has been made in favor of designing the company for insertion into the financial market despite most companies' actual needs. ${ }^{67}$ The securities market requires

65 The Hong Kong Companies Ordinance brings family relationship in at a number of points to attribute the interests of family members to the corporate actor. Hong Kong Companies Ordinance, (2014) Cap. 622, §§ 281, 486, 667, 674) (H.K.) [hereinafter HKCO].

66 The ability to attract such outside investors is then ultimately enshrined as a key element of economic development. See Rafael La Porta et al., Legal Determinants of External Finance, 52 J. FIn. 1131, 1149 (1997).

67 The costs of external finance were clearly explained as early as Stewart C. Meyers, The Capital Structure Puzzle, 39 J. Fin. 575, 581 (1984). A recent view, apparently based on insights from the official study of the U.K. equity markets which John Kay led, can be found in John Kay, Other People's Money: Masters of the Universe Or Servants of 
fungible units of value that can be traded knowing that their issuer has a single purpose fungible to other issuers to act in such a way that these units of value increase in price. The decision to conceive the corporation as a financialized entity forms the basis for much of traditional corporate governance scholarship. ${ }^{68}$

\section{TWo Common Value Networks That USE THE CORPORATION: FAMILY AND THE STATE}

\section{A. Family Firms: Loyalty Transcending Contract}

Of the value networks in the social environment that might co-exist with a company, perhaps the most common is the family. ${ }^{69}$ Family firms ${ }^{70}$ are widespread, if not dominant, in most economies. The Family Firm Institute (FFI) gathers data from a number of sources (including Harvard Business School and KPMG) to provide the following estimates on the portion of economic activity represented by family firms:

THE PEOPLE? (2015) (“Stock markets are not a way of putting money into companies, but a means of taking it out .... While railways, car manufacturers and brewers needed additional funds to build new plant as they expanded, new companies today-such as Apple or Google - commonly become generators of cash, rather than users, early in their lifetime.").

68 See supra discussion in Part IV, Section A.2.

69 A potential competitor for this title might be the corporate group. If simple groups are included, such constellations of companies are indeed common. Corporate groups also can have an overall purpose that has systemic value and cannot be boiled down to a single group company. Because the members of the group are individual companies, however, it differs from the kind of system under analysis in this paper, where members of the (family or state) system are also corporate actors with specific duties. Nevertheless, it is worth undertaking a parallel systemic analysis for the special ways in which groups make use of the corporate form. See, e.g., the extensive treatment of these questions in PHILLIP I. Blumberg et AL., Blumberg ON Corporate Groups (2d ed. 2004).

70 The definition of "family firm" varies among scholars and jurisdictions, but generally includes elements of both family control and family management. In this paper, the concept of family firm used accommodates the varying specifics of different definitions and corresponds to the recent observations of the European Economic and Social Committee: "It is generally accepted that family businesses can be characterized within three circles: families, businesses and ownership structure. The impact of the family on the other two circles determines the family nature of the company. This impact means that family businesses are more complex than their non-family counterparts." See, e.g., EUROPEAN ECon. And Soc. Comm., FAmily Businesses in Europe AS A Source of RenEwed Growth AND BETTER JobS (2015), http://www.eesc.europa.eu/?i=portal.en.int-opinions.34702 [https://perma.cc/U58M-FY5N]. 
- In the United States, at least half of all companies and just over half of listed companies;

- In Europe, approximately $60 \%$ of all companies;

- In China, approximately $85.4 \%$ of private sector enterprises; and

- In India, approximately $79 \%$ of organized private sector employment. $^{71}$

As the oldest and most prevalent social organization, the family has its own organizational logic. Hirschman, in Exit, Voice and Loyalty: Responses to Decline in Firms, Organizations, and States, uses family as his primary example of an organization where there is a high degree of loyalty. ${ }^{72}$ Because the family is an organization in which socialization begins at birth and continues (at least nominally) until death, it has the potential to exhibit an intense unity that far outstrips that arising from ad hoc employment positions or membership stakes in a stock corporation. This characteristic is evident in firms of all dimensions, from the neighborhood restaurant to family empires like that of the Rothschild ${ }^{73}$ or Walton families. ${ }^{74}$

This systemic logic of the family as an organization gives family firms certain recurring characteristics. These include

71 Global Data Points, FAM. FIRM INST., http://www.ffi.org/?page=GlobalDataPoints [https://perma.cc/CF89-K2JB] (last visited Feb. 17, 2017). When compiling this data, FFI uses the definition formulated by Miller et al.: "Family Firm[s] [are those] in which multiple members of the same family are involved as major owners or managers, either contemporaneously or over time." Danny Miller et al., Are Family Firms Really Superior Performers?, 13 J. CoRP. Fin. 829, 836 (2007). See also Clifford G. Holderness, The Myth of Diffuse Ownership in the United States, 22 REV. Fin. STUD. 1377 (2009); International Family Enterprise Research Academy, Family Businesses Dominate, 16 FAM. Bus. REV. 235 (2003) (providing further data that presents a stronger presence of family firms).

72 Albert O. Hirschman, Exit, Voice and Loyalty: Responses to DeCline in Firms, ORganizations, AND STATES 77-78 (1970).

73 " [T] he history of the firm is inseparable from the history of the family: the phrase 'the House of Rothschild', which has been used by previous historians (and film-makers) was used by contemporaries, including the Rothschilds themselves, to convey this unity." Niall Ferguson, 1 The House of Rothschild: Money's Prophets: 1798-1848 (1998).

74 There are too many differences between the rise of Rothschild banking in 19th century Europe and that of Walton retailing in 20th century America to achieve any more with this reference than a reminder that the family firm can take many different shapes yet retain its familiar nature. 
generally recognized features, such as a pronounced drive for both longevity and autonomy of the firm, ${ }^{75}$ in which the effect of the family as an organization independent of and with a timeframe different from the company becomes visible as such. The family itself will be as long-lived as its progeny and will remain genetically distinct, so that its presence within the company structure will tend to drag the corporation in the direction of these two characteristics. From a systemic point of view, longevity and autonomy are predictable characteristics of a company that contains a controlling family. The particular characteristics of the family as an organization can also lead to another common trait of family firms, which is a concerted effort to preserve a specific culture, ${ }^{76}$ something many non-family firms attempt to project as well.

Other features of family firms are less well-recognized. Broad-based empirical studies of large firms have shown that founder controlled family firms significantly outperform non-family firms in terms of profitability, particularly when founders are heads of the board. ${ }^{77}$ Other studies, discussed below, show how the independent network of the family coexisting with the company's governance framework supplements and supports management. Looking at Chinese firms, Amit et al. found that when external institutions are poor, the presence of family ownership adds significant value to a

75 See, e.g., Thomas Markus Zellweger et al., From Longevity of Firms to Transgenerational Entrepreneurship of Families: Introducing Family Entrepreneurial Orientation, 25 Fam. Bus. REv. 136, 136-51 (2012); G.T. Lumpkin et al., Long-Term Orientation: Implications for the Entrepreneurial Orientation and Performance of Family Businesses, 22 EnTREPRENEURShip \& Regional DeV. 11-24 (2010); Timothy G. Habbershon et al., A Unified Systems Perspective of Family Firm Performance, 18 J. Bus. VENTURING 451, 452 (2003).

76 Bennedsen and Fan recount how the Mulliez family created an academy to train its family members for the business over a 100-year period, distilling the culture of the group's founder and passing it on to family members to run the firm of some 175,000 employees. BENNEDSEN \& FAN, supra note 12, at 2, 4.

77 See generally, Roberto Barontini \& Lorenzo Caprio, The Effect of Family Control on Firm Value and Performance: Evidence from Continental Europe, 12 EUR. FIN. MGMT. 689 (2006); Belen Villalonga \& Raphael Amit, How Do Family Ownership, Control and Management Affect Firm Value? 80 J. Fin. Econ. 385 (2006); Ronald C. Anderson \& David M. Reeb, Founding-Family Ownership and Firm Performance: Evidence from the S\&P 500, 58 J. Fin. 1301 (2003). 
firm. ${ }^{78}$ From an institutional point of view, this is exactly what we would expect when a robust system like the family is used in a context that lacks other competent ordering systems. Anderson et al. found that, "[b]ecause of the unique incentives generated by long-term commitments to the firm, undiversified portfolios, and familial pressure, founding families appear to reduce agency conflicts between the firm's equity and debt claimants and thereby reduce the cost of debt financing."79 Others have found empirical support for the arguments that family firms have more efficient channels for informal decision-making ${ }^{80}$ and overall lower transaction costs. ${ }^{81}$ All of these findings are consistent with an understanding that the family brings an existing system of relationships, communication, and trust into the mechanisms of corporate law and does not depend on the law for its own operational efficiency. While this is partially recognized in the way current corporate governance treats family relationships as sources of interest conflicts, the systemic nature of the network is generally ignored.

\section{B. The Family Firm in Asia}

Although, as observed above, the family firm is prominent in all major economies, there are particular historical reasons why this form of business is particularly dominant in the private sectors of Asian economies. Throughout history, Asia and the West have followed very different paths of development. In Europe, the incubator of Western culture, the core cultural institution of Christianity weakened the extended family as a key social institution. Grief observes:

This was achieved by such policies as prohibiting marriages among kin . . . encouraging the donation of

\footnotetext{
78 Raphael H. Amit et al., The Role of Institutional Development in the Prevalence and Value of Family Firms (Harv. Bus. Sch. Fin., Working Paper No. 1507823, 2010), http://ssrn.com/abstract=1507823 [https://perma.cc/ZZ5R-SNJX].

${ }^{79}$ Ronald C. Anderson et al., Founding Family Ownership and the Agency Cost of Debt, 68 J. Fin. ECON. 263, 283 (2003).

${ }^{80}$ Catherine M. Daily \& Marc J. Dollinger, An Empirical Examination of Ownership Structure in Family and Professionally Managed Firms, 5 FAM. Bus. REV. 117, 124 (1992).

${ }^{81}$ Craig E. Aronoff \& John L. Ward, Family-Owned Businesses: A Thing of the Past or a Model of the Future?, 8 FAM. BUS. REV. 121, 122-23 (1995).
} 
one's inheritance to the church, advocating consensual marriages, and condemning practices that enlarged the family, such as polygamy, divorce and remarriage. . . . By the late medieval period, kin-based social structures were no longer at the center of European institutional complexes. The rise of alternative, nonkin-based social structures in such forms as communes, guilds, fraternities, and universities is a hallmark of this time.... [T] he relative absence of both kin-based social structures and an effective state in late medieval Europe led the Europeans to progressively rely on corporations: non-kin-based, self-governed, interest-based social structures. ${ }^{82}$

Grief offers detailed comparison of European and Muslim development and shows that "[c]ollectivist cultural beliefs were a focal point" in the culture of Muslim merchants, where kin-based organizations thrived. In contrast, "individualistic cultural beliefs were a focal point among the [European] Genoese," 83 where non-kinbased organizations thrived. The individual, as the basic social unit, came to inhabit non-kin-based institutions, including the corporation, at various levels within society. ${ }^{84}$

Like that of Muslim society, Asian history has differed markedly from the institutional history of Europe in stressing relationships over individuals. Glenn explains: "East Asian tradition ... did not generate a notion of individual rights . . . [there is a] refusal to conceptualize individuals in any other way than relational-as children, parents, friends ... and on and on." ${ }^{95}$ This state of affairs reflects the central teaching of Confucianism to focus

\footnotetext{
82 Avner Greif, Institutions and the Path to the Modern Economy 252 (2006) (citing Jack Goody, The Development of the Family and Marriage in Europe 135 (1983) on the specific practices introduced.).

${ }^{83} \mathrm{Id}$. at 281.

${ }^{84}$ From his own conceptual perspective, Hegel describes how the members of a family whose business is inserted into a corporation overcome the limits of self and family in order to achieve a more honorable stance as member of the corporation. However, like the family, the corporation ultimately inhibits the unmediated relationship between the individual and the civil society and state. G.W.F. Hegel, ElEmENTs of THE PHILOSOPHY OF Right 271-273 (Allen W. Wood ed., H. B. Nisbet trans., Cambridge Univ. Press, 1991) (1820).

85 H. Patrick Glenn, Legal Traditions of THe World 337 (4th ed. 2010).
} 
on the "Five Cardinal Relationships" (wu lun) in which filial piety is central. ${ }^{86}$ Ruskola explains a difference in this regard on interpersonal bonds. "[J]ust as contract is the paradigmatic form of private ordering in [the American] legal system today, so family was the ideological paradigm of traditional Chinese private ordering."87 The family remains the central social institution, even in countries that have experienced decades of communism, as the estimate that family firms constitute about $85 \%$ of the Chinese private sector business makes clear. ${ }^{88}$ Gatfield and Youseff go so far as to assert that the "popularity and commonality of the Chinese family-owned business is both an affront and a holistic challenge to the nature of the three-fold societal structure and individualistic economic capitalism of western modernity." ${ }^{89}$ This particular assertion runs contrary to data showing that, as in the West, Asian family enterprises tend to outperform nonfamily firms, provided that control and cash-flow rights are in balance, ${ }^{90}$ i.e., control is not achieved through a pyramid structure or share classes allowing disproportionately low investment.

It is also true that just as the family can buttress corporate governance and operations mechanisms, it can threaten them. As a matter of system logic, it can be expected that when family integrity and dynamism are congruent with the requirements of a given stage of a given firm's development, a family firm will be competitive. For the same reason, if the motivations generated within a family were to deviate from the needs of the business because, e.g., the family system experiences a significant disruption, the family as secondary system would then drag on the efficiency of the company. In Hong Kong, the Li family that controls Cheung Kong Holdings and

86 Seok-Choon Lew et al., Confucian Ethics and the Spirit of Capitalism in Korea: The Significance of Filial Piety, 11 J. E. AsIAN STUD. 171, 175 (2011). "No other culture or religion puts more meaning on family than Confucianism, because the Confucian family carries the religious meaning of eternal life." $I d$. at 179 . "Individuals exist as parts constituting the whole in the form of family - that is, as unity, not as independent units." Id. at 180.

87 Teemu Ruskola, Conceptualizing Corporations and Kinship: Comparative Law and Development Theory in a Chinese Perspective, 52 StAN. L. REv. 1599, 1608 (2000).

${ }^{88}$ FAM. FIRM INST., supra note 71.

${ }^{89}$ Terry Gatfield \& Mark Youseff, A Critical Examination of and Reflection on the Chinese Family Business Unit and the Chinese Business Clan, 14 FAM. Bus. REV. 153, 154 (2001).

90 Stijn Claessens et al., Disentangling the Incentive and Entrenchment Effects of Large Shareholdings, 57 J. Fin. 2741, 2743 (2002). 
Hutchison Whampoa is not known for displaying family discord. The founder, Li Ka-shing, who turned eighty-nine in 2017, has focused considerable effort both on succession and the future of the family firms by rationalizing the corporate group. ${ }^{91}$ One of Li's competitors in property development, the Sun Hung Kai Group, has been less fortunate in family affairs. Following the death of its founder, Kwok Tak-seng, his three sons Walter, Raymond, and Thomas took over the company, but the oldest son was kidnapped and suffered trauma, affecting his management of the company in subsequent years. ${ }^{92}$ When the younger brothers (perhaps prematurely) stepped in to fill the breach, at least one of them (Thomas) became involved in activity with a government official that in 2014 earned him and the government official prison sentences for bribery. ${ }^{93}$

The trial of Thomas and Raymond Kwok for bribery brought two major Chinese value systems into contact. The trial was not only the first of its kind in Hong Kong but was launched in the same year that mainland China's anti-corruption drive began. ${ }^{94}$ It is impossible to say that this highly unusual action against one of Hong Kong's wealthiest families was in no way related to events set in motion by the CCP in mainland China. Indeed, there has been some further friction between the state and a prominent family. In 2015, Li Kashing was publicly criticized by a CCP publication for divesting from

91 See (1) Cheung Kong Reorganisation Proposal-Change of the Holding Company of the Cheung Kong Group from Cheung Kong to CKH Holdings by way of a Scheme of Arrangement, (2) Merger Proposal- (a) Proposed Acquisition by the Hutchison Group of 6.24\% of the Common Shares of Husky in issue and (b) Proposed Share Exchange Offer to the Hutchison Scheme Shareholders for the Cancellation of all the Hutchison Scheme Shares by way of a Scheme of Arrangement, and (3) Spin-off Proposal-Proposed Spin-off and Separate Listing of the Property Businesses of the CKH Holdings Group on the Stock Exchange by way of Introduction (Jan., 9 2015). HKEXNEws, http://www.hkexnews.hk/ (last visited June 30, 2016).

92 Joe Studwell, Asian Godfathers: Money and Power in Hong Kong And SOUTHEAST AsIa 264 (2007).

93 See, e.g., Stuart Lau, Rafael Hui and Thomas Kwok Found Guilty of Bribery in Hong Kong's Biggest Graft Trial, South China Morning Post (Dec. 19, 2014), http://www.scmp.com/news/hong-kong/article/1665519/rafael-hui-and-thomas-kwokfound-guilty-bribery-hong-kongs-biggest [https://perma.cc/JW74-5YL3].

94 Brian Spegele, China Anticorruption Cases Have Quadrupled Since 2013, Study Says, WALL ST. J. (Dec. 11, 2015), http://blogs.wsj.com/chinarealtime/2015/12/11/chinaanticorruption-cases-have-quadrupled-since-2013-study-says [https://perma.cc/4XTRM4SB]. 
China and reorganizing his group under Cayman Islands law. ${ }^{95}$ There are certainly historical reasons why the CCP might find itself in arguments with powerful bourgeoisie families, ${ }^{96}$ but today the structural arguments might be more powerful. Both families and the CCP bring an external system of operations into a corporation whose governance is designed to coordinate individuals divorced from such systems. These two value systems are present in the controlling shareholders of nearly every major company in China (including Hong Kong). For this reason, among others, the CCP will be the other major social system examined in this paper.

\section{Party Firms: Ideology and Ambition Transcending the Immediate Profit Motive}

Ruskola has observed that in China there are express conceptual links between what society expects from extended families and what it expects from the CCP. ${ }^{97}$ Today, most of the largest Chinese corporations are owned by the People's Republic of China and controlled by the CCP, which directly controls the appointment of senior management and indirectly controls their policy choices for the company. ${ }^{98}$ These firms are some of the largest in the world. ${ }^{99}$ Like a family, a political party is not organized

95 Bruce Einhorn, The Tycoon Left Out in the Cold: China Accuses a Billionaire of Forsaking the Fatherland, BlOOMBERG BusinessweEK (Oct. 9, 2015), http://www. bloomberg.com/news/articles/2015-10-08/china-s-attack-on-li-ka-shing-spooks-hongkong-s-elite [https://perma.cc/6U3G-77UU].

96 Beyond the historical animosity between the two groups, the CCP has recently begun a path similar to that of traditional corporate governance theory by viewing families as inherently suspect because their alternative network offers tunneling potential to extract benefits of control and transfer them to peripheral family members. See, e.g., Simon Denyer \& Xu Yangjing, China Vows to Tackle 'Family Corruption'-But Even State Media Can't Hide Its Skepticism, WASH. Post (Apr. 29, 2016), https://www.washingtonpost.com/ news/worldviews/wp/2016/04/29/china-vows-to-tackle-family-corruption-but-even-statemedia-cant-hide-its-skepticism [https://perma.cc/L8P2-W44Z].

97 Teemu Ruskola, Conceptualizing Corporations and Kinship: Comparative Law and Development Theory in a Chinese Perspective, 52 StAN. L. REV. 1599, 1608 (2000).

98 Jiangyu Wang, The Political Logic of Corporate Governance in China's StateOwned Enterprise 47 CoRnell InT'L L.J. 631, 651-660 (2014); Hon S. Chan, Cadre Personnel Management in China: The Nomenklatura System, 1990-1998, 179 CHINA Q. 703, 704 (2004); MCGREGOR, supra note 11, at 67-69.

99 According to Fortune Magazine, in 2015 Chinese state owned enterprises ranked as follows on a global scale: State Grid (2nd in Global 500), China National Petroleum (3rd), Sinopec Group (4th), Industrial and Commercial Bank of China (15th), China Construction 
primarily to generate profits, and like a family, the roles, duties and motivations within the network of a political party will not necessarily be congruent with the scheme projected by corporate law. Unlike a family, political parties involved in such management activities are neither ancient (although they are long-standing) organizations of humanity nor seen by the majority of existing scholarship as having any positive impact on the company. As will be discussed below, the relationship between the CCP and Chinese SOEs is generally seen as contradictory, but with a system-oriented theory of corporate law it need not be so.

In China, the state is the ultimate owner of most of the country's largest commercial, industrial and energy enterprises, with its holdings managed by the Chinese central government's StateOwned Assets Supervision and Administration Committee (SASAC). ${ }^{100}$ These enterprises currently exist as stock corporations, the result of a process of "corporatization" undertaken in the 1990s. ${ }^{101}$ Although many of them are listed on stock exchanges in China and abroad, SASAC retains a controlling interest in these SOEs. While the executive managers of such companies are duly appointed in conformance with shareholder vote under Chinese company law, decisions regarding the nominees for such positions are made by the CCP's Central Personnel Committee, which MacGregor calls "without a doubt the largest and most powerful human resources body in the world."102 As explained in the Joint Opinions on Strengthening and Improving Party Building Work in Central SOEs, the Central Personnel Committee must participate in "the appointment, management and supervision of all SOE officers above the middle level."103 The Committee will examine the candidate's qualifications and deliberate on their possible appointment, then "the appointment

Bank (22nd), China State Construction Engineering (27th), Agricultural Bank of China (29th), Bank of China (35th), China Mobile Communications (45th). Global 500, ForTunE (Aug. 19, 2016), beta.fortune.com/global500 [https://perma.cc/25DT-XEFU].

100 The list of firms held by SASAC. SASAC, Yangqi Minglu (央企名录) [List of State-Owned Enterprises] (Dec. 20, 2016), http://www.sasac.gov.cn/n86114/n86137/ index.html [https://perma.cc/SV94-UFLL].

${ }^{101}$ Wang, supra note 98, at 646 (noting that the project of corporatization was undertaken in tandem with the promulgation of China's first Western-style companies act in the modern era). See also WANG, supra note 30, at 6.

102 MCGREGOR, supra note 11, at 69.

103 Wang, supra note 98, at 658 (providing the translation used here on Joint Opinions on Strengthening and Improving Party Building Work in Central SOEs). 
of the candidates by the board of directors [will take place] based on the recommendations of the Party Committee, following all legal procedures and formalities." 104 When CCP members are appointed to positions by a CCP screening committee, we must assume that Party principles will be an important determinant of the way that these appointees interact with each other and the company. Like the family, the CCP presents a system defining interpersonal relationships, so that corporate actors will not meet the traditional expectation under corporate law of individually autonomous profitdriven actors within the firm.

Wang refers to this mix of CCP control and corporate formalities as "a system of corporate governance that features two parallel structures, one for legal governance and the other for political governance." ${ }^{105}$ Wang argues that CCP policies are carried into the corporate behavior of the SOEs through four channels: (i) members of the CCP are required to follow party philosophy and policies; (ii) the CCP appoints party members to the executive management positions within the SOEs; (iii) party cell meetings are conducted regularly by SOE employees at various levels; and (iv) because the CCP has its own disciplinary channels for party members, these channels also apply to party member executives in SOEs. ${ }^{106}$ McGregor puts it more cryptically, citing a lawyer who advises Chinese state firms: "'In corporate law, the boards [of Chinese state companies] can choose to disregard the Party's advice. As a fact of life, they cannot." "107

Viewed from the perspective of systems theory, one can see how the presence of the CCP within a corporation gives corporate actors dual roles and duties, so that one system intermingles with and influences the other. The CCP has its own ideological position, and this does not always correspond to profit maximization or "shareholder value." Wang explains that within Chinese society, a key aspect of CCP legitimacy is providing economic stability and prosperity, and that the SOEs are a tool in this process through directing the use of economic resources, implementing industrial

\footnotetext{
104 Id. at 659.

105 Id. at 648 .

106 Id. at 652.

107 MCGREGOR, supra note 11, at 49 (quoting a securities lawyer familiar with Chinese companies).
} 
policy and even collaborating in Chinese foreign policy. ${ }^{108}$ In following government policies, the SOE could be understood to carry out a very general form of socially targeted corporate sustainability, or corporate social responsibility (CSR). McGregor sees this as a clear disadvantage: "Far from being driven solely by making a profit for shareholders, the Party had to act in accord with social 'stability' and national 'macro-economic' policies laid down by the government." 109 He further notes, "[t]he corporate animal that emerged from the protracted and painful birth of China Inc. was a strange new beast ... it was both commercial and communist at the same time." 110 Wang offers a concrete example of SOE behavior diverging from pure profit motive; following major earthquakes, SOEs have been called upon to "participate in the rescue efforts by providing services and materials"111 to quake victims.

Such socially oriented philosophy has also led to atypical patterns in executive compensation. Executive managers given stock options when an SOE prepared for an IPO often did so with an understanding within the CCP that the options were not to be exercised. MacGregor notes that these executives were deprived of "huge windfalls" generated by rising stock prices, and quotes the dilemma as expressed by someone close to the situation: "These executives say, I have added value, so I should be rewarded,' said a Chinese banker. 'The Party says, you have added value because we put you there." "112 This approach to executive compensation would be extremely rare in a Western company, but after the global financial crisis began in 2007, it has been an approach that is increasingly considered. ${ }^{113}$

The "parallel structures" of corporate governance found in Chinese SOEs present "a new model of SOE governance that combines universal elements of corporate law with communist political institutions." 114 McGregor well sums up how this model

108 Wang, supra note 98, at 660, 661.

109 MCGREGOR, supra note 11, at 52.

110 Id.

111 Wang, supra note 98, at 663.

112 McGRegOR, supra note 11, at 102.

113 See, e.g., Steven A. Bank et al., Executive Pay: What Worked? (UCLA School of Law, Law-Econ Research Paper No. 16-11), http://ssrn.com/abstract=2812349 [https:// perma.cc/DY6N-UVL6].

114 Wang, supra note 98 , at 667. 
might be grasped by the international capital markets when he characterizes expressions of policy loyalty as cronyism, "timely genuflections at the feet of the Party by officials, and indicative of political loyalty and reliability, both essential to a career in public life." 115 Wang asks the more academic, and probably more pertinent, question as to whether "this experiment will be successful and sustainable."116 There are some signs that history could be moving favorably in the Chinese direction. The Western model of executive compensation has been shown to present significant problems. General support for creating a socially sustainable philosophy of company law is growing. Western countries use tax law to encourage all individuals (including corporations) to participate in charitable activities such as disaster relief.

When the systematic unity of a network of values - like that promoted by a political party - is incorporated into corporate law, the contradiction between maximizing individual profit and maximizing general systemic welfare (or merely executing a party platform) can be mitigated. As will be explained in Part IV, lawmakers have been generous (and generally successful) in bringing the values of the financial system into the rules governing the corporate form. Similar accommodations can be made for other systems of value, whether the family, a political party, or a philosophy of social values pursued by corporate founders.

\section{AdJUSTING CORPORATE LAW WITH STRUCTURAL COUPLINGS}

\section{A. How Current Corporate Law Flexibly Accounts for Its Environment}

1. Individuals Adhering to Rules Constituting a Single System

What is possibly still the leading theory of the firm understands corporate law as establishing a framework within which individuals meet and transact through a "nexus of contracts" to create

\footnotetext{
115 McGregOR, supra note 11, at 67.

116 Wang, supra note 98, at 669.
} 
their respective rights and duties. ${ }^{117}$ While differing political positions argue that rights, duties and the benefits of corporate operations should be attributed differently among the various corporate constituents, neither law nor theory in the leading traditions of company law ${ }^{118}$ provide for wholesale interaction of alternative systems of value within the company. ${ }^{119}$ Persons with power under corporate law (usually directors, but also including controlling shareholders and executive management, depending on the jurisdiction) must act in the best interests of the company or some constituent thereof and avoid conflicts of interest. ${ }^{120}$ Such conflicts are expressed in terms of self-interest, which is extended to cover links to systems (such as other companies or the family) where an

117 "Indeed, one can see corporate law in general as effectively a delegation to the legislature and the courts of the continual reformation and reinterpretation, as circumstances and strategies change, of the indefinitely long-term relational contract among a corporation's shareholders, managers, and creditors that is constituted by the corporation's charter." Henry Hansmann \& Reinier Kraakman, Reflections on the End of History for Corporate Law, Yale L. \& Econ. Res. No. 449, Aug. 2011, at 14. See also Palgrave-MacMillan, Convergence of Corporate Governance: Promise and Prospects (2012); Cheffins, supra note 49, at 13 (citing MARC T. MoOre, Corporate Governance In the SHAdOW of THE STATE 62, 67 (2013)).

118 There are good arguments supporting the view that the German corporate law framework is already systemic in its view that duties run to the overall "enterprise" (Unternehmen). See MERTENS \& CAHN, supra note 49, §§ 76, 33, 37 (3rd ed. 2010). Indeed, the relational value of rights is deeply imbedded in modern German law. The German constitutional guarantee of property right, for example, is already systemic in its basis: "Property and the right of inheritance shall be guaranteed .... Property entails obligations. Its use shall also serve the public good.” GRUNDGESETz [GG] [Basic Law] art. 14. (Ger.), translation at https://www.bundestag.de/blob/284870/ce0d03414872b427e57fccb703634dc d/basic_law-data.pdf [https://perma.cc/9DK4-MWVV].

119 An argument can also be made that when Hansmann and Kraakman refer to "the political power of the various interest groups" vying for predominance within the corporate entity, they imply that each of these groups brings its systematic network of values into the fray. Hansmann \& Kraakman, supra note 117, at 13. Although this does give insight into the play of power and the reasons for influence enjoyed by any given corporate constituency, it does not examine the manner in which various elements of each value system interact. As such, their theory does not focus on the interaction of systems within the corporate form.

${ }^{120}$ In all major jurisdictions, directors must avoid or declare any interest that conflicts with that of the company. With respect to directors, see, e.g., DGCL, supra note 40, § 143144,; Companies Act 2006, supra note 34, §§ 172-173, 145-177, 182; HKCO, supra note 65, § 536 (H.K.); David Chien v. Francis Cheung, [2013] H.K.E.C. 896 (noting that with respect to controlling shareholders, the duty is found in the US jurisdictions.); Weinberger v. UOP, Inc., 457 A.2d 701 (Del. 1983); Jones v. H.F. Ahmanson \& Company, 460 P.2d 464 (Cal. 1969). 
interest can be found. ${ }^{121}$ These systems thus become visible only as a manifestation of an individual interest of a corporate actor influenced by them. Law acknowledges one system, the company itself. Other networks of systematic value are not recognized as such, with a few exceptions. When the conflict comes from a source beyond the individual corporate actor, it will be attributed to that actor if the type of relationship is deemed capable of channeling the interest. ${ }^{122}$ The remainder of the network through which the interest is channeled rarely falls within the contemplated coverage of corporate governance rules.

\section{The Exceptional Role of the Financial System}

The accommodations within corporate law to allow the company's smooth connection to the financial system are pervasive and deeply embedded in the structure of the corporation as governed by law. As such, these features need not be announced and are often

121 DGCL $\S 144$ extends its rule on conflict of interests in company transactions to an interest held by, "any other corporation, partnership, association, or other organization in which 1 or more of its directors or officers, are directors or officers, or have a financial interest." DGCL, supra note 40, § 144. Sections 175 and 177 of Companies Act 2006 also apply to conflicts of interest that are "indirect" although they do not refer to interests of a person that is "connected" with a director, where "connected" expressly includes family members. Companies Act 2006, supra note 34, §§ 252-253. For provisions regulating a company's extension of credit to directors, Companies Act $2006 \S 200$ includes such connected persons, which encompasses family members. Hong Kong company law is similar in this regard. Its provisions regulating extension of credit to a director apply to loans to a "connected entity," and these entities include nuclear family and persons cohabiting with the director. HKCO, supra note 65, §§ 486, 500-503. However, the realities of businessessuch as banks and international firms providing expatriate employees with housing - are addressed in a detailed set of exceptions to the prohibition, which allow loans to be made in connection with ordinary business or employee housing schemes. HKCO, supra note 65, § 509 (exception for home loan), HKCO, supra note 65, § 510 (exception for leasing goods and land), HKCO, supra note $65, \S 511$ (exception for transaction entered into in ordinary course of business). Such balancing of power, prohibition, and exception is exactly what we would expect, given that corporate law provides society with an artificial construct for the convenience of associated undertakings of entrepreneurs and investors. The remaining question is then why the Ordinance does not provide a more articulated set of options for attributing interests between family members.

122 The law's understanding of exactly what can channel an interest is far less substantiated than it could be. Historically existing aggregations of common economic interest (family, company and partnership) are included automatically, while other aggregations long recognized in sociology and economics (club, class and school networks) would have to be alleged and proven. Suspicion of political party influence is found in economics and corporate law scholarship, but not in the law itself. 
taken for granted. The stock corporation is conceived theoretically and organized legally as a means of concentrating the financial investments of many contributors into a single entity through public issue of shares in that entity. ${ }^{123}$ In this way, corporations could expand their capital beyond a size achievable by a small group of wealthy partners. The financial system, like other systems, has its own internal needs. Members of this system interact to make payment transfers, allocate capital, manage financial affairs and provide tools to manage risk. ${ }^{124}$ The capital allocation and risk management functions require a limit on volatility for the value of assets they trade, "liquidity" through the ability to transfer such assets with satisfactory immediacy to others, and a cap on the amount of uncertainty arising from the risk of fraud by market participants or issuers of securities. ${ }^{125}$ The legal form of the stock corporation was designed and has over the years been repeatedly adjusted to meet these needs.

At the level of design, stock corporations have basic features recognized in most jurisdictions: legal personality, investor ownership, limited liability, transferable shares, and central management. ${ }^{126}$ Four of these characteristics are closely tied to the needs of secondary market trading in negotiable instruments, a market that is much older than even the early stock corporations. ${ }^{127}$ Corporate shares are transferable by default, ${ }^{128}$ and these shares

123 See, e.g., 1 Palmer's Company LaW $§ 1.1$ (Geoffrey Morse ed., 2016); FrankLin A. Gevurtz, Corporate Law 19-34 (2d ed. 2010); Paul Davies, Gower and Davies Principles of Modern Company LaW 11 (8th ed. 2008); EIlis Ferran, Principles of Corporate Finance LaW 3 (2008); Robert C. Clark, Corporate LAW 1-4 (1986); AdolF A. Berle, Jr. \& Gardiner C. Means, The Modern Corporation and Private Property 11-17 (revised ed. 1968); 1 William MEAdE FletCHER, FletCHER CyClOPEDIA OF THE LAW OF CORPORATIONS § 2 (1931).

124 See Kay, supra note 67, at 203. Other influential lists of main activities for the financial system have of course been created. See, e.g., FrankLin Allen \& Douglas Gale, Comparing Financial Systems 25-45 (2000); Ross Levine, Financial Development and Economic Growth: Views and Agenda, 35 J. ECON. LiTERATURE 688, 717-720 (1997).

125 See, e.g., Mervyn King, The End of Alchemy: Money, Banking And the Future of THE GLOBAL ECONOMY 204-225 (Kindle ed. 2016).

126 See Andreas Cahn \& David C. Donald, supra note 10, at 9-19 (containing a discussion of other sources).

127 Fernand Braudel, The Wheels of Commerce 100-101 (1992).

128 The shares of "private" companies in the U.K. tradition cannot be freely offered to the public. See, e.g., Companies Act 2006, supra note 34, § 755. In Hong Kong, express 
evidence ownership interests in a separate legal entity that in turn owns its own assets and whose ability to pay liabilities is not tied to the assets of individual owners, thus shielding the company from claims against its owners and the owners from claims against the company. ${ }^{129}$ This furthers the stability of the value of traded shares. Rules in connection with the fifth characteristic, central management, allow financial investors to protect themselves against the radical uncertainty arising from human behavior, such as fraud. ${ }^{130}$ These are the rules of which alternative systems such as families and the state habitually run afoul, but the rules are rarely breached when action is taken to protect financial actors because those actors are the intended beneficiaries of the rules. ${ }^{131}$

Over the years, this basic company structure designed for complementarity with the needs of the financial system has been amended to augment such complementarity. Action intermediated by duties and the threat of litigation was understood as an overly indirect and expensive way to insure that managers behave in a way that brings the best results to financial investors. A solution offered was to bring the action of the financial system directly within the relationship between management and the company by making management themselves financial market investors. ${ }^{132}$ Executive compensation was redesigned in the 1980s to compensate management with stock and stock options, aligning the interests of management and financial market investors. ${ }^{133}$ Companies were correspondingly given the power to issue derivative products in the

provisions must be included in the company's articles of association restricting transfer of shares in such companies. HKCO, supra note 65, § 11.

129 See, e.g., Henry Hansmann et al., Law and the Rise of the Firm, 119 HARV. L. ReV. 1333 (2006).

130 This is the central "agency problem" discussed in corporate law theory. See, e.g., KRAAKMAN ET AL., supra note 2, at 78-82.

131 The results of this structural characteristic in corporate law has been discussed from a different angle with significant effect in LynN StOUT, The SHAREHOLDER VALUE MYTH: How Putting Shareholders First Harms Investors, Corporations, and the Public (2012).

132 See, e.g., Richard A. Booth, Give Me Equity or Give Me Death-The Role of Competition and Compensation in Building Silicon Valley (University of Maryland Legal Studies Research Paper No. 2006-442006), http://ssrn.com/abstract=940022 [https://perma. cc/2APT-GU5A].

133 See Carola Frydman \& Raven E. Saks, Executive Compensation: A New View from a Long-Term Perspective, 1936-2005, 23 Rev. Fin. STUD. 2099 (2010); Bank, Cheffins \& Wells, supra note 113, at 8-9. 
form of options on their own shares. Other changes were made to facilitate financial investors to bid up the price of a company's shares, turning control of an entire company into something that could be easily traded. ${ }^{134}$ This was done by introducing codes and lawsformulated by or meeting the needs of financial investors - to prevent management from impeding a hostile takeover of the company. ${ }^{135}$ Pagano points out that in Continental Europe, the presence of labor organizations and families as concentrated alternative networks within companies checked the evolution of the company toward an object of transfer on the financial markets. ${ }^{136}$

Finance extends beyond equity investment. In order to mediate between the needs of two types of financing parties, shareholders and creditors, shares are sold for a specific amount, with the payment remaining as capital in the company for the protection of creditors, and this share capital may not be paid out to shareholders as dividends. ${ }^{137}$ In company law following the U.K. tradition, a unique form of security interest called "charges" were developed in corporate law to protect secured lending, and these charges were given properties allowing them to fluidly self-adjust from "floating" to "fixed" through a process referred to as "crystallization," which

${ }^{134}$ Kay, supra note 67, at 840-854 (discussing Henry G. Manne, Mergers and the Market for Corporate Control, 73 The Journal of Political EConomy 110 (1965)). On the interests backing the creation of takeover rules, see John Armour \& David A. Skeel Jr., Who Writes the Rules for Hostile Takeovers, and Why?: The Peculiar Divergence of US and UK Takeover Regulation, 95 GEORGETOWn L. J. 1727 (2007).

135 See The Panel on Takeovers and Mergers, The Takeover Code, Rule 21 (2016) (U.K.).

136 "In the European case, case, the personality of the business corporation was saved from its "thingness" by its identification with the fate of the family dynasty and by the countervailing powers of the unions." Ugo Pagano, Economic Things, Legal Persons and Hybrid Business Corporations 24-25 (Feb. 2017) (unpublished manuscript) (on file with author)

137 A number of issues have arisen over the years in these two forms of investor protection. One is the gradual elimination of the concept of "par value" in some jurisdictions, which is not seen as reducing the amount of share capital available for creditor protection. Another is the elimination of a required "minimum capital" in the United States, but not in Europe, and the debate on whether minimum capital does protect creditors. A third adjustment of rules on sale of shares under value in connection with granting stock options for managers and other employees of the company. See, e.g., William A. KLEIN \& John C. Coffee JR., Business ORganization AND FinANCE: LEgAL AND ECONOMIC PRINCIPLES 228230 (10th ed. 2010); Bayless Manning \& James J., JR. HANKs, Manning’s Legal CaPital (3rd ed. 1990). 
enables a creditor instantly to scoop up the entire aggregate of an enterprise's assets upon occurrence of a specified credit event. ${ }^{138}$

Such rules restrict the freedom of the company to finance itself as opportunity arises and also can restrict its ability to comply with contractual obligations to constituents such as employees, but the restriction has been traditionally viewed as a source of freedom: any protection of the interests of financial investors is deemed fundamentally salubrious for the company's development. ${ }^{139}$ Moreover, where the needs of the financial system advise exceptions to these rules, such exceptions are routinely implemented. Thus, although using share capital to pay for new shares offered to new investors can be understood to damage both earlier investors (who made real capital contributions) and creditors (who do not want capital depleted through distributions to shareholders), the underwriting industry expects a fee for its service, so that offering a discount on an issue of shares to pay such fees can be understood as valuable. ${ }^{140}$ The pattern of reasoning used-facilitating the financial system's connection to companies strengthens such companies-is dominant in corporate law policymaking, so paying the fee to financial actors is actually considered a savings rather than a transaction cost because the focus is placed on the funding gained rather than the fee paid. We introduce significant modifications into corporate law to stimulate such access to finance despite the fact that a successful company might well finance itself cheaper and better through revenue from ongoing operations. ${ }^{141}$ Even when connection with the value system of the financial markets is not the best choice for a company, such companies still must operate within a basic structure that was designed to accommodate such connection.

\footnotetext{
138 See National Westminster Bank Plc v. Spectrum Plus Ltd., [2005] 2 A.C. (H.L.) 680.

139 The link between investor protection and corporate growth has been made by Rafael La Porta et al., supra note 66.

140 Companies Act 2006, supra note 34, § 553; HKCO, supra note 65, § 14.

141 See, e.g., Meyers, supra note 67; Kay, supra note 67. Some distinction is already present in corporate law between the minority investor protection in listed or public companies and that in unlisted, private and closely held companies. However, at least in U.K. and U.S. state corporate law statutes, there is no deeply embedded distinction in the nature of the corporate form for those that will seek outside financing and those that will not.
} 


\section{Equitable Duties are Doors to Alternative Value Systems}

When a court applies the duty of care to the action of a corporate director, deciding whether it was undertaken with "reasonable care, skill and diligence"142 or "on an informed basis, in good faith," 143 the court must necessarily draw values from systems in the social environment beyond law that determine the relationship of an actor to an action or a contracting party. Moreover, in both the United Kingdom and Hong Kong, the company law expressly requires that a director exercise the "the general knowledge, skill and experience that the director has," 144 which requires an examination of skills brought from the environment into the company. This has led to decisions that consider practices in industries such as the taxation of international trusts ${ }^{145}$ and the management of firms engaged in derivatives trading. ${ }^{146}$ In Delaware, the requirement that directors act "on an informed basis" is generally fulfilled if they are fully briefed by a financial institution in a way that meets industry standards. ${ }^{147}$ Although the financial system may be the related set of values in the environment most commonly brought into corporate law to determine whether a duty has been fulfilled, there is no limit on the sets of skill and standards that could be injected into corporate law for such purposes.

4. "Equitable Considerations" Are a First Step in Systemic Accommodation

In Hong Kong, the United Kingdom, and a number of jurisdictions of the Commonwealth, law provides minority shareholders with a remedy if the affairs of the company have been

142 Companies Act 2006, supra note 34, § 174(2)(a); HKCO, supra note 65, §465(2)(a).

143 Aronson v. Lewis, 473 A.2d 805, 812 (1984).

144 Companies Act 2006, supra note 34, § 174(2)(b); HKCO, supra note 65, §465(2)(b).

145 Norman v. Theodore Goddard, [1991] BCLC 1028 (U.K.).

146 Chintung Futures Ltd (in Liquidation) v. Arthur Lai Cheuk-Kwan [1994] 1 H.K.L.R. 95.

147 In Unocal Corp. v. Mesa Petroleum Co., 493 A 2d 946 (1985), directors were found to have acted on an informed basis because "The board then received a presentation from Peter Sachs on behalf of Goldman Sachs \& Co. (Goldman Sachs) and Dillon, Read \& Co. (Dillon Read) discussing the bases for their opinions ... show[ing] slides outlining the valuation techniques used by the financial advisors, and others, depicting recent business combinations in the oil and gas industry." 
conducted in a manner unfairly prejudicial to the plaintiff shareholder (individually or as a class). ${ }^{148}$ The activity complained of is not "misconduct"-i.e., a breach of the law or a duty-but rather an action by persons controlling the company that contravenes some (spoken or unspoken) arrangement reached among members. ${ }^{149}$ This differs from the fiduciary duty of controlling shareholders under Delaware law ${ }^{150}$ because it looks to the actual constellation of relationships within the company in order to understand whether such an arrangement exists. While breaches of formal contractual arrangements are included in the sources of this action, the more common situation is where some course of dealings among the parties have created an understanding for which it is equitable to bar contravention of the arrangement. These equitable considerations arise primarily in connection with understandings among family members and persons in a 'quasi-partnership' relationship. ${ }^{151}$ That is, they arise when shareholders have agreed that a second system of values will operate within the company parallel to the rules established by corporate law.

A recent case in which violation of equitable considerations arising from a family relationship was found to trigger unfair prejudice shows how corporate law can be made to accommodate a second systems within its rules of governance. In 2015, the Hong Kong Court of Final Appeals held that patterns of behavior among two brothers created equitable considerations supporting an action for unfair prejudice. ${ }^{152}$ A company's founder built up an international corporate group from 1930 until 2004, when he died. His two sons had worked with him for decades managing the group. Following the father's death, the younger son began skillfully to maneuver to exclude his brother and his brother's offspring from management and other benefits of control, increasing distributions to himself, his heirs and companies they control. All of this was legal. The Court made clear, however, that the family relationship as it existed during the

\footnotetext{
148 Companies Act 2006, supra note 34, § 994; HKCO, supra note 65, § 724.

149 In re Saul D. Harrison \& Sons Plc., [1995] 1 BCLC 14 (U.K.).

150 See, e.g., Kahn v. Lynch Communication Systems, Inc., 638 A.2d 1110, 1114 (1994) (stating that a shareholder owes a fiduciary duty to a corporation only if it owns a majority interest in the corporation, or exercises control over the business affairs of the corporation).

151 O’Neill v. Phillips, [1999] 1 WLR 1092 (U.K.).

152 Yung Kee Holdings Ltd., FACV 4/2015 (C.F.A. Nov. 11, 2015) (Legal Reference System) (H.K.).
} 
founder's lifetime established an expectation that the older brother would be included in company decision-making regardless of his shareholdings, so that subsequent actions of the defendant brother unfairly prejudiced the plaintiff. ${ }^{153}$ The values expressed in the family system created the framework that the court enforced through this action. Corporate law could accommodate such secondary systems in other ways as well.

\section{B. Coupling the Users of Corporations into Corporate Law}

If expectations generated by the family as secondary system intersecting with corporate law can be used to ground a personal action against another shareholder in corporate law, there is no real structural impediment to bringing such systems more actively within the corporate law framework. The notion of "equitable consideration" on which the unfair prejudice action is based can be understood as an existing "structural coupling" in corporate law between the legality established by the law and the patterns of behavior established by the family using the corporate form. In the Yung Kee decision, discussed above, it is very unlikely that the court would have considered an increase in the company's earnings per share as a mitigating circumstance to the prejudicial exclusion of the older brother from management. Expanded use of such couplings would allow users of the corporate form whose motives are influenced by systems such as families or a political party to operate within the company without running afoul of its design generally privileging the individual profit motive and more specifically the needs of the financial investor. The following paragraphs provide examples that remain more theoretical than practical in nature.

\section{Legitimizing Family Use of the Corporate Form}

As discussed in Part III, family firms are known to favor values such as autonomy, longevity and culture, and the family network brings with it properties like alternative channels of communication and agency bonding through relationships of loyalty. It is possible to couple such values into the governance structure of

153 Id. ๆๆ 54-56. 
corporate law without major structural adjustments. An amendment of the law to allow directors to incorporate such values into board decision-making could be formulated very much like a typical constituency protection provision. The U.K. Companies Act contains the beginnings of such a provision, expressly allowing directors to take into account the interests of the likely consequences of any decision on "the interests of the company's employees," "the need to foster the company's business relationships with suppliers, customers and others," and "the impact of the company's operations on the community and the environment," among other things. ${ }^{154}$ Although the first subsection subordinates such aims to promoting "the success of the company for the benefit of its members as a whole," the second subsection allows a corporate purpose as stated in the articles of association to set out different goals. ${ }^{155}$ Such purposes could include any particular value or cluster of values held to be important by the family using the particular company. In this way, a family member director could act to promote a family value without a conflict of interest just as a shareholder director may not act to promote the value of shares without fearing condemnation for conflict of interest.

If values important to a family were incorporated expressly in the object of a company or in other provisions in the articles of association or incorporation, they would additionally have an affirmative (rather than just a protective) function, achieving somewhat broader accommodation of the family into the corporate form. Hong Kong law gives the articles of association the force of a contract under seal among all members and the company, ${ }^{156}$ so that family aims and practices could be enforced by direct action against any member and any director (for failing to cause the company to comply). A similar action is available against directors that act outside of the stated object of the company. ${ }^{157}$ Patterns of behavior existing in gaps between such express declarations but necessary to carry them out could then constitute equitable considerations on

154 Companies Act 2006, supra note 34, § 172(1).

155 Companies Act 2006, supra note 34, § 172(2) ("Where or to the extent that the purposes of the company consist of or include purposes other than the benefit of its members, subsection (1) has effect as if the reference to promoting the success of the company for the benefit of its members were to achieving those purposes").

${ }^{156}$ HKCO, supra note 65, § 86. A provision with like effect is found in Companies Act 2006, supra note 34, § 33.

157 HKCO, supra note 65, § 116(3). 
which an action in unfair prejudice — or a specially devised actioncould be based.

The adjustments discussed above to couple family and corporate form would allow significant progress in accepting the family as a legitimate user of the corporation. Actions influenced by family aims would no longer constitute conflicts of interest, and thus would have achieved a status similar to the aims expressed in the financial system. Like financial system imperatives, family aims could also be positively pursued and this pursuit would have an avenue of enforcement. However, to reach the proper level of accommodation, the structure of governance should also be adjusted. Under Hong Kong law, the selection and tenure of company directors is provided for in the articles of association. The law itself in most cases refers to "directors" rather than "board of directors" when defining their powers and duties. ${ }^{158}$ With this enabling framework, it should also be possible to constitute a supervisory board and management board dichotomy in the articles of association to manage the company. The supervisory board could be selected from family members using any method these members see fit to incorporate into the articles and the management board could either be selected by the supervisory board or by a vote of all shareholders (including both family and non-family participants), or some other method. The supervisory board would constitute a structural coupling between family decision-making and company management.

In addition to accommodating a family network through adjustment of corporate purpose and organization of governance, the equitable fiduciary duty and duty of care should be open to adjustment. This could be achieved through either statute or case law. The key to the inclusion of an alternative system like a family within the corporate form is that the relationship arising from the environmental system should be permitted to influence the behavior of corporate actors to the extent necessary for the internal operation

158 For example, a search of the HKCO shows only four uses of the term "board of directors," each time referring to the power of a holding company to influence the board of its subsidiary. By contrast, the nearly 400 other references to board action or acts by individual directors use the term "directors" or "director." For example, in ascribing the duty of informing shareholders of the state of the company before each annual general meeting, the law uses the phrase, a "company's directors must prepare for each financial year a report." HKCO, supra note 65 , § 388. 
of the relevant system. Values embodied in such environmental systems should be considered on a par with the values of such systems as the secondary market for securities. If a company director were to take action to increase the share price - even if only temporarily — it would likely be evaluated as wholly positive under existing corporate law, even if all benefit were to go to traders in the secondary market, rather than to the company or its stable members.

The law should thus account for the particular, systemic logic of management behavior in a family, just as it would import principles from accounting, finance or any other appropriate body of organized knowledge recognized as relevant under corporate law. Just as a director's decision might be judicially validated if made to save a company tax payments is taken under best-practice advice by a competent financial institution, or seen to reduce the risk against the default of a counterparty, so too should duties allow strategic rationale from a family system in order to protect company values, such as to preserve autonomy, preserve a given culture, or reduce succession risk at times of generational handover.

\section{Legitimizing the CCP in Chinese SOEs}

As discussed in Part III, Chinese SOEs currently operate under rules of corporate governance very similar to those used in any major system of corporate law. Nevertheless, members of management are selected by the CCP and expected to carry out broader social policies set by the CCP. These parallel planes of governance operate without any particular method of mutual accommodation or even transparency regarding their existence. Particularly because the CCP governs China as a fully sovereign country with control over its legislative process, this contradiction between law and practice is both unusual and unnecessary. Structural couplings similar to those discussed above for the family could be easily incorporated into corporate law, and nothing but the disapproval of international investors could hinder China from doing so.

First, the company law could be amended so that directors could be both allowed to follow CCP policy without fear of breaching a duty to the company and also required to do so. Second, if policies set by the CCP are recognized as objects of the company, affirmative 
actions available to members would exist to ensure their enforcement, both against directors and - through an action similar to unfair prejudice - against shareholders. This would allow China to sell control of SOEs without abandoning the company's commitment to CCP policy. Third, the existing two-tier board structure of Chinese companies could be used to create a structure in which CCP members populate one board that then controls the population of a second board, which could be opened up to any qualified manager. As mentioned above, because China is a sovereign with control over its own laws, only market disapproval could prevent China from making such changes to its law.

The model of company law China has accepted is designed for use by the financial system, and investors would certainly prefer that this remain the only system beyond corporate law that is allowed to shape the corporate form. Particularly in light of the probability that the large Chinese SOEs do not finance themselves primarily on the financial markets, ${ }^{159}$ but though revenues from ongoing operations, a continued primacy of the financial system over Chinese company law seems unjustified. While international investors may at first impression find such accommodation dangerous to their interests, they should understand that such exercise of power in any case exists, and its exercise within an orderly and transparent framework brings not only dignity to the Chinese state (which currently bends the law in a dubious manner), but also predictability and transparency for investors.

If China as sovereign were to undertake such amendments, they could be made neutral to a system, so that both families using private firms and the CCP using SOEs could employ the corporate form without being hampered by the inherited subordination of corporate law to the needs of the financial system.

159 A sample of ten prospectuses issued by major SOEs in connection with their initial public offerings shows that six planned to use the proceeds to "strengthen their capital base," another had no plans for the funds, and only three expressed any intention to actively invest the proceeds or pay down debt. The six companies that injected the funds into capital were China Construction Bank Corporation, Industrial and Commercial Bank of China Ltd, Bank of China Limited, China Life Insurance Company Limited, Ping An Insurance (Group) Company of China, Ltd.; the one with no plans was Tencent Holdings Limited; and those with concrete uses for the funds were PetroChina Co Ltd, China Shipping Container Lines Co Ltd, and China Telecom Corporation Limited. 


\section{CONCLUSIONS}

Corporate law in its current form is surprisingly rigid and blind to the other systems of value that operate in interlocking relationships within companies as essential parts of the corporate environment. These systems are recognized in corporate law primarily to the extent that they influence a corporate actor, and such influence is often condemned as a conflict of interest. When the stock corporation is conceived as a closed system with only the most marginal recognition of the various value networks intersecting with it, the corporate form becomes far less useful than it could otherwise be. This state of affairs is particularly disturbing in Asia where most companies are operated by families. In China, a very significant number of the largest firms in the economy are owned by the state and guided by the CCP. If we take the theoretical step to understand corporate law as a system, the systems theory of Niklas Luhmann allows us to create "structural couplings" that can be introduced between corporate law and systematic networks of value such as family, the state, or a political party.

To begin the exercise of coupling corporate law with its environment, this paper has singled out two ideologically opposed examples - the commercially active family and the CCP within Chinese SOEs - as social systems of value that make use of the corporate form to pursue commercial ends. The values of such systems are not always congruent with the rights and duties provided for in traditional corporate law, which have been designed mainly to facilitate and protect trading in corporate shares on secondary capital markets. Such fundamental features of corporate law like legal personality, limited liability and transferable shares exist in order to meet the needs of the financial system. While protection of investors in such markets is a goal that should be taken into account, it should not be overvalued. For large companies, initial public offerings may be of little use as a source of finance, and their utility as a form of prestige and advertising must be balanced against the pressure the IPO generates for short-term focus. The goals of the controlling shareholders operating a company's planning in the markets for products and services are much more important for a corporation's viability than the needs of secondary market traders. Secondary market traders make no capital contribution to the company except 
the promise of liquidity, and this promise actually serves financial investors themselves more directly than it does the capital costs of the issuing company and the financial position of its controlling shareholders, who in most cases have no plans to engage in active trading.

Particularly in light of the fact that the corporate form has been repeatedly adjusted to the needs of the financial markets, it is highly unusual that changes have not yet been made to allow efficient use of the company by organizations such as families, whose driving logic does not always accord with the prevalent logic of corporate law. Further adjustments can be made to accommodate other systems. Both the measure of skills in the duty of care applied to directors and the equitable considerations used to determine whether a company has been operated in an unfairly prejudicial manner are examples of structural couplings linking corporate law to the surrounding environment.

In the same way, the duties of directors and the objects of the company can be adjusted toward systemic aims of the family or a political party like the CCP to couple their needs with corporate law. Moreover, the arrangement of management organs can be easily adjusted in the Hong Kong legal system (where such organs are shaped in the articles of association) or in mainland China (whose legal system is controlled by the CCP) to introduce a dedicated board for family or party members to meet and make decisions. In China, the fact that corporate law reflects the financial-market-focused model leads to distortions of corporate governance, which creates a significant and troublesome discrepancy between law-on-the-books and law-as-enforced. The only barrier to the Chinese government enacting corporate law that allows for efficient use of the corporate form by its SOEs or family firms is the displeasure of international investors and the perceptions of market quality that track their interests.

Beyond family firms and SOEs, the same use of structural couplings could integrate CSR or governance design for corporate sustainability deeply within the operation of a corporation. This work could be pursued within the same systems theory model of analysis. If corporate law continues to disregard deep-seated and powerful value systems that interlock with most of the corporations operating globally, and those calling for a more socially responsible corporate 
form do not look to systemic change, the corporate form will remain inefficient for its users and overly supportive of its own financialization. An adjustment of the basic architecture, however, could trigger substantial synergies between such systems and the company. 